\title{
Electrochemical assessment of pigments-binding medium interactions in oil paint deterioration: a case study on indigo and Prussian blue
}

\author{
Antonio Doménech-Carbó ${ }^{* *} \mathbb{D}$, María Teresa Doménech-Carbó ${ }^{2}$, Laura Osete-Cortina ${ }^{2}$, Margherita Donnici ${ }^{3}$, \\ Núria Guasch-Ferré ${ }^{4,6}$, Rosa M. Gasol-Fargas ${ }^{5}$ and Manuel Ángel Iglesias-Campos ${ }^{4,6}$
}

\begin{abstract}
The degradation of laboratory oil paint film specimens containing indigo and Prussian blue pigments and pictorial samples from the Sant Francesc de Paula painting exhibited in the Tomàs Balvey Arxiu Museum (Cardedeu (Catalonia), Spain) has been studied by voltammetry of immobilized particles. This technique, combined with light microscopy, scanning electron microscopy-energy dispersive X-ray analysis, nanoindentation-atomic force microscopy, attenuated total reflectance-Fourier-transform infrared spectroscopy and gas chromatography-mass spectroscopy techniques permits the proposal of a dual scheme for the degradation of the pigments when naturally aged and submitted to accelerated UVA aging. Under conditions of moderate temperature, humidity and natural illumination, and low gradients of these parameters, Prussian blue acts as a radical scavenger moderating the production of reactive oxygen species produced in the oil binding medium by the action of ultraviolet radiation, resulting in the formation, in the

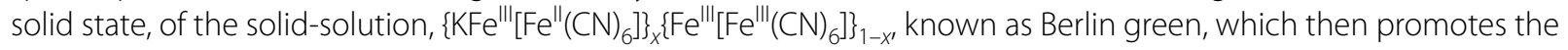
formation of indigo adducts with radicals. In several localized areas of the Sant Francesc de Paula paint showing strong degradation, Prussian blue acts as a promoter of the indigo oxidation to isatin, thus resulting in a considerable chromatic shift.
\end{abstract}

Keywords: Electrochemistry, Oil paints, Prussian blue, Indigo, Deterioration

\section{Introduction}

The deterioration of oil paintings is an important problem in the field of conservation and restoration of cultural heritage. Understanding of degradation processes is difficult due to the variety of organic and inorganic materials which constitute the pictorials layers, and by the variety of external factors promoting paint deterioration. These include the action of light, humidity, microorganisms and mechanical and thermal stress [1-4]. The deterioration

\footnotetext{
*Correspondence: antonio.domenech@uv.es

1 Departament de Química Analítica, Universitat de València, Dr. Moliner, 50,46100 Burjassot, València, Spain

Full list of author information is available at the end of the article
}

of oil films is associated to crosslinking reactions, oxidation of unsaturated acids and hydrolysis of glyceride bonds releasing free fatty acids. The role of pigments in such deterioration processes has received considerable attention due to their possible ability for inhibiting and catalyzing oil drying [2,5-7], formation of metal soaps [8-12], and mineralization $[9,12]$.

In order to study oil paints degradation processes, a variety of analytical techniques have been used, including, among others, image analysis [13], infrared spectroscopy $[5,11,14,15]$, scanning electron microscopy image analysis [12], and Raman spectroscopy [16].

The interaction between pigments and oils has been subject of different studies, concentrated in lead
Springer Open

(c) The Author(s) 2020. This article is licensed under a Creative Commons Attribution 4.0 International License, which permits use, sharing, adaptation, distribution and reproduction in any medium or format, as long as you give appropriate credit to the original author(s) and the source, provide a link to the Creative Commons licence, and indicate if changes were made. The images or other third party material in this article are included in the article's Creative Commons licence, unless indicated otherwise in a credit line to the material. If material is not included in the article's Creative Commons licence and your intended use is not permitted by statutory regulation or exceeds the permitted use, you will need to obtain permission directly from the copyright holder. To view a copy of this licence, visit http://creativeco mmons.org/licenses/by/4.0/. The Creative Commons Public Domain Dedication waiver (http://creativecommons.org/publicdomain/ zero/1.0/) applies to the data made available in this article, unless otherwise stated in a credit line to the data. 
pigments $[12,13,17,18]$ and Prussian blue $[19,20]$. The mutual pigment-oil interaction has also been subject of study. In particular, the increase in stiffness and brittleness as well as the formation of extractable compounds of low molecular weight (mono- and dicarboxylic short chain fatty acids) exhibited by aged oil paintings. These alterations have been attributed on one side to the release of fatty acids due to hydrolysis processes undergone by the triacylglycerol molecules present in the drying oils [4] and, on the other hand, to the formation of metalcarboxylate complexes between the free fatty acids and the ionomeric forms of pigments present in the paints $[21,22]$. Prevalence of one of these two processes as the mechanism mainly responsible for the loss of mechanical properties of paintings during aging has been subject of scientific controversial discussion [4], so that studies devoted to the elucidation of mechanisms of interaction of oil medium and specific pigments can help to clarify this issue. In this line can be framed the study on the laser-induced degradation of indigo and Prussian blue applied with an oil binder on a musical instrument by De Santis et al. [23].

In this context, the voltammetry of immobilized particles, a solid state electrochemistry technique developed by Scholz et al. [24-26], can be applied. This technique consists of the record of the voltammetric response of a solid sample (few nanograms if necessary) abrasively transferred onto the surface of an inert (usually graphite) electrode in contact with a suitable electrolyte in which the solid is insoluble or sparingly soluble. Due to its sensitivity to different redox states and its ability to work with samples at the level of few nanograms, this technique is of application in the fields of archaeometry, conservation and restoration, as summarized in different reviews [27-29]. In previous works, we have described the use of this electrochemical methodology to characterize the biodegradation of cadmium yellow [30] and verdigris [31] pigments in reconstructed egg tempera and egg-linseed oil emulsion paint films. Here, we present a solid state electrochemistry study, complemented by optical microscopy, scanning electron microscopy coupled to energy dispersive X-ray detection (SEM-EDX), nanoindentation-atomic force microscopy (NI-AFM), attenuated total reflectance-Fourier transform infrared spectroscopy (ATR-FTIR), and gas chromatographymass spectrometry (GC-MS) on the interaction between two blue pigments, indigo and Prussian blue, and linseed oil in paintings, comparing the results from an old painting showing peculiar alteration features and a set of reconstructed paint specimens naturally and artificially aged.

This multi-technique approach was developed with the aim of providing a broader view, and hence, to attain a deeper understanding of the formation mechanism of the alterations exhibited by the oil painting, Sant Francesc de Paula, by an anonymous artist in the eighteenth century, which is currently included in the painting collection of the Tomàs Balvey Arxiu Museum (MATBC, Cardedeu, Spain) with reg $n^{\circ} 2258$ [32]. As it can be seen in Fig. 1a, the painting surface showed significant chromatic alterations in several light-blue parts of the background painting mainly from the sky, as well as in some of the areas of trees and vegetation. During the conservation treatment and the cleaning process carried out at the Laboratori de Conservació-restauració de l'Oficina de Patrimoni Cultural de la Diputació de Barcelona, it was suspected that the darkened layer did not belong to an applied coat of varnish or other resin, but was possibly due to a transformation of the original materials. The painting technique appears to be oil on canvas applied over a thick ground layer prepared with natural earths, following the characteristic techniques used in this period. Vertical fissures and loss of paint indicate that, at some point, the canvas was rolled up, and later on was mounted with cotton lining applied with animal glue onto a wooden frame. These vertical fissures were caused by mechanical abrasion removing some of the dark colored superficial layer. Although the work was unfinished leaving an irregular faded surface over the blue and green paint layers, the conservation process possibly also included some facing, cleaning and re-varnishing of the surface [33].

Figure $1 \mathrm{~b}, \mathrm{c}$ shows details of the altered and unaltered blue areas of the painting in which samples were taken for analyzing. Our analytical data (vide infra) indicated the presence of a mixture of indigo, Prussian blue and lead white in this light blue area of the sky, thus providing opportunity for studying the possible interactions between these pigments and the organic binder. The current study exploits the electroactive character in solid state of both Prussian blue [34-36] and indigo [37-40]. Due to their extended use, the photochemical degradation of these pigments has claimed considerable attention [41-44].

\section{Experimental}

\section{Instrumentation}

Morphological examination and elemental analysis of the cross-sections of the paint samples, previously carboncoated, were performed using a JEOL JSM 6300 scanning electron microscope operating with an Oxford Instruments Link Isis X-ray microanalysis system controlled by Inca software. The analytical conditions were: accelerating voltage of $20 \mathrm{kV}$, beam current of $2 \times 10^{-9} \mathrm{~A}$, working distance of $15 \mathrm{~mm}$. Qualitative analysis was performed mainly in punctual and area modes. Quantitative microanalysis was carried out using the ZAF method. This 

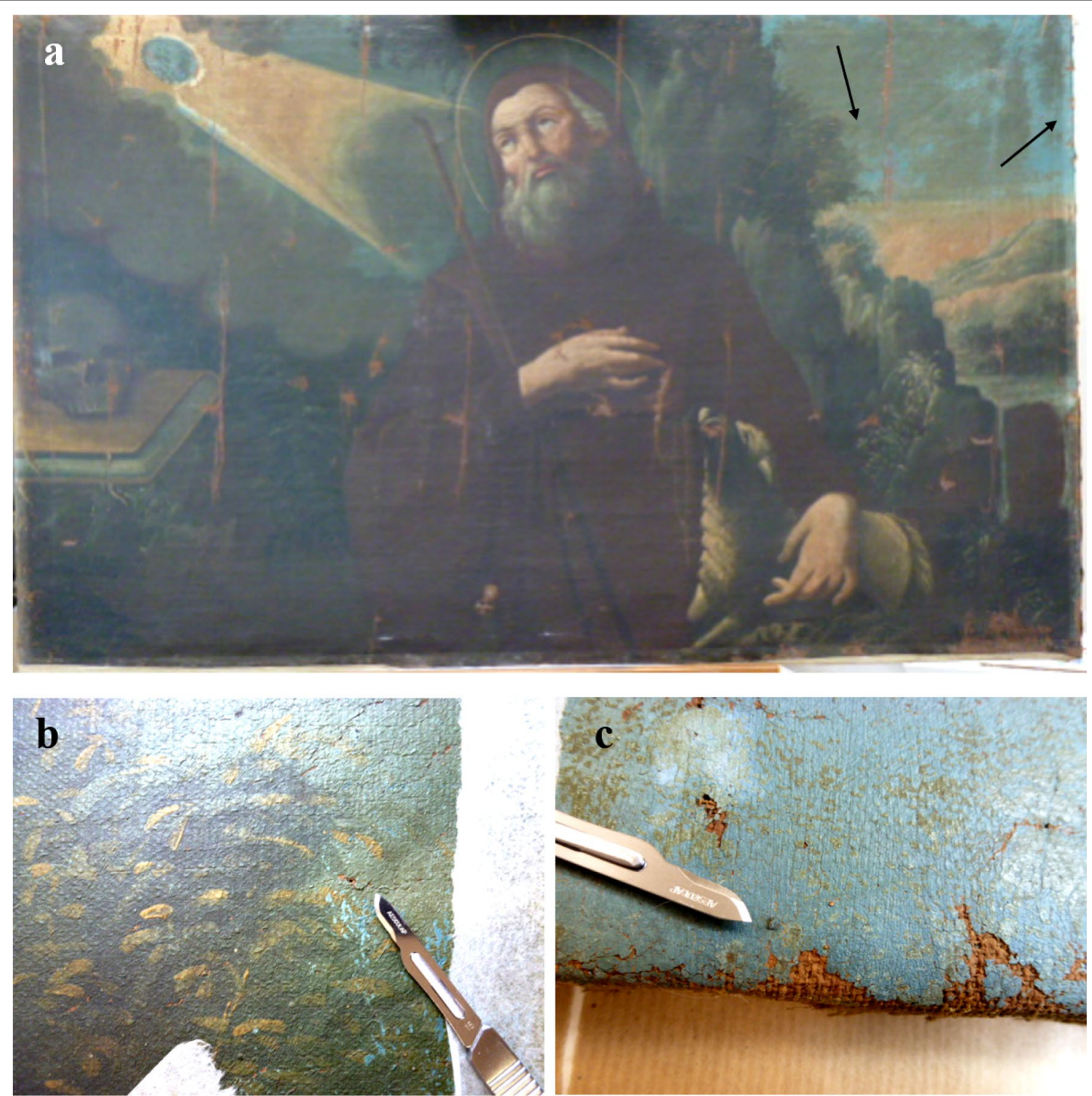

Fig. 1 Photograph of the "Sant Francesc de Paula" painting (a). The arrows mark the points were the paint samples were taken from altered (b) and unaltered $(\mathbf{c})$ areas

method is defined as a mathematical correction of the matrix effect that takes place in the simultaneous determination of the concentration of each element present in a multielement material. This theoretical method provides a correction of the X-ray intensity of each element present in the material by means of the application of a series of correction factors for the atomic number effect $\mathrm{Z}$, which describes the depth of electron penetration and the fraction of electrons that backscatter from the sample, the absorption correction $\mathrm{A}$, which describes the absorption of X-rays in the matrix as a function of the composition and depth of electron penetration and the fluorescence $\mathrm{F}$ of one element by the others present [45]. In this study, the counting time was $100 \mathrm{~s}$ for major and minor elements. Concentrations were calculated by stoichiometry from element percentages generated by ZAF method used with the Oxford Instruments Link Isis EDX instrument.

NI-AFM is an advanced instrumental technique that allows the determination of the elastic modulus $(E M)$ in the microsamples of the original paintings. In this study, a Multimode AFM (Digital Instruments VEECO Methodology Group, USA) with a NanoScope IIa controller was used, which was equipped with a J-type scanner (max. scan size of $150 \times 150 \times 6 \mathrm{~mm}^{3}$ ). Repeatability of height 
values has been experimentally estimated in $10 \%$. The $E M$ of each sample was obtained from the scan asyst peakforce quantitative nanomechanical system $(Q N M)$ with a tip Scan Asyst (Bruker) $\left(\mathrm{k}=3 \mathrm{~N} \mathrm{~m}^{-1}\right)$. The ScanAsyst ${ }^{\mathrm{TM}}$ algorithm self-optimizes the atomic force microscope when operates in Peak Force Tapping mode so that scan parameters such as setpoint, feedback response, and scan rate are automatically selected and constantly adjusted. The $E M$ values were calculated by the Bruker Nanoscope 1.40 Analysis software. This process was carried out using the Derjaguin, Muller, Toropov model [46]. The tip radius $R$ is calculated by an indirect method using a polystyrene sample with a known $E M$ of $2.7 \mathrm{GPa}$. The indirect method includes the prior determination of deflection by pressing the tip onto a Sapphire disc, and the spring constant of the cantilever by performing a thermal tune. A value of 0.3 was used for the Poisson's ratio. This value is recommended for samples with an $E M$ that falls within the $1 \mathrm{GPa}<E M<10 \mathrm{GPa}$ range. $E M$ value was collected automatically by the instrument for each pixel of the image. Images with $10 \times 10 \mu \mathrm{m}^{2}$ areas that consisted of 256 lines by pixels, and taken at a scan rate of $0.4-0.5 \mathrm{~Hz}$, were created for each sample during one same scan, which allowed the morphological data in high (2D and 3D) and peak force modes and $E M$ to be collected. $E M$ was calculated as the average value of the individual $E M$ measured in each pixel of an image. At least, three images were acquired in each sample. Repeatability was at ca. $10 \%$. More details on the procedure used for calculating the $E M$ of samples are found elsewhere [47] and also provided as Additional file 1 . The $E M$ values provided by the NIAFM are representative of the mechanical behaviour at micro/nanoscale of the paint layer in the tested area of the same. Therefore, the $E M$ values provided by the NI-AFM are not corresponding with those other obtained from macroscopic test specimens using conventional mechanical testers. Nevertheless, this technique is very useful in the study of real paintings for two main reasons, on one side, the conventional mechanical testers require specimens in the range $(1 \times 5 \times 0.01) \mathrm{cm}$ and, therefore, experiments on real paintings are not available due to sampling restrictions associated to the uniqueness of the artworks. In contrast, NI-AFM is available as the experiment can be performed on samples in the micro or nano scale. On the other hand, the $E M$ data obtained using NI-AFM in different samples, i.e. unaltered and altered areas of paintings are comparable thus enabling a quasi-non invasive methodology for evaluating changes in the mechanical behaviour of real paintings due to aging or alteration processes.

Infrared spectra of the paint samples and the reconstructed paint films were recorded using a Vertex 70 Fourier-transform infrared spectrometer (Brucker) with a fast recovery deuterated triglycine sulphate temperature-stabilized coated detector and a MKII Golden Gate Attenuated Total Reflectance accessory. A total of 32 scans were collected at a resolution of $4 \mathrm{~cm}^{-1}$ and the spectra were processed using the OPUS 7.2/IR software.

A gas chromatograph Agilent $6890 \mathrm{~N}$ (Agilent Technologies, Palo Alto, CA, USA) coupled to an Agilent $5973 \mathrm{~N}$ mass spectrometer (Agilent Technologies) was used for the identification of the binding medium of the painting. A capillary column HP-5MS (5\% phenyl-95\% methylpolysiloxane, $30 \mathrm{~m}, 0.25 \mathrm{~mm}$ i.d., $0.25 \mu \mathrm{m}$ film thickness, Agilent Technologies) was used to adequately separate components. Polar and non-polar compounds were separately analyzed by the hydrolysis procedure, followed by derivatization with ethyl chloroformate, as described elsewhere [48]. $1.5 \mu \mathrm{L}$ of the chloroformic solutions of amino acid or fatty acid derivatives obtained were injected into the GC-MS system in the split mode (split ratio 1:20). Chromatographic conditions for the amino acid derivatives were initial temperature of $100{ }^{\circ} \mathrm{C}$ increased with an initial ramp of $5{ }^{\circ} \mathrm{C} \min ^{-1}$ up to $155^{\circ} \mathrm{C}$ and then a final ramp of $15^{\circ} \mathrm{C} \mathrm{min}-1$ up to $300^{\circ} \mathrm{C}$ held for $10 \mathrm{~min}$. For the fatty acid derivatives the chromatographic conditions were: initial temperature of $50{ }^{\circ} \mathrm{C}$ held for $2 \mathrm{~min}$, increased by $20^{\circ} \mathrm{C} \mathrm{min}{ }^{-1}$ up to $300{ }^{\circ} \mathrm{C}$ and held for $10 \mathrm{~min}$. The helium gas flow was set at $1.3 \mathrm{~mL} \mathrm{~min}^{-1}$. Electronic pressure control was set to the constant flow mode with vacuum compensation. Ions were generated by electron ionisation $(70 \mathrm{eV})$. The mass spectrometer was scanned from $\mathrm{m} / \mathrm{z} 20$ to $\mathrm{m} / \mathrm{z} 800$ in a 1 -s cycle time. Mass spectrometer tuning was checked using perfluorotributylamine. EI mass spectra were acquired by the total ion monitoring mode. The interface and source temperatures were $280^{\circ} \mathrm{C}$ and $150{ }^{\circ} \mathrm{C}$, respectively. Agilent Chemstation software G1701CA MSD was used for the GC-MS control, peak integration and mass spectra evaluation. Library of Mass Spectra and National Institute of Science and Technology (NIST) were used to identify compounds.

Electrochemical experiments were performed in a three-electrode cell at $298 \mathrm{~K}$ using $0.25 \mathrm{M}$ sodium acetate buffer (Panreac) at pH 4.75 as a supporting electrolyte. In order to reproduce the conditions accessible to portable equipments, no deaeration of the electrolyte was carried out. A CH I660C potentiostat (Cambria Scientific, Llwynhendy, Llanelli UK) was used. Sample-modified commercial paraffin-impregnated graphite bars (Alpino HB type, $68 \% \mathrm{wt}$ graphite, diameter $2 \mathrm{~mm}$ ) were used as working electrodes completing the three-electrode arrangement with a platinum wire counter-electrode and an $\mathrm{Ag} / \mathrm{AgCl}(3 \mathrm{M} \mathrm{NaCl})$ reference electrode. Optionally, semi-derivative convolution of data was carried out in order to enhance peak resolution using the $\mathrm{CH}$ software. Prior to each measurement, the graphite electrode was 
polished with alumina, rinsed with water and polished by pressing over paper. Then, the electrode was pressed onto the sample deposited on the plane surface of an agate mortar. Sample-modified graphite electrodes were then dipped into the electrochemical cell so that only the lower end of the electrode was in contact with the electrolyte solution.

\section{Samples and test specimens}

Two paint samples from the unaltered light-blue and the altered greenish areas from the sky were taken using a scalpel (Fig. 1b, c). For the optical and scanning electron microscopy studies, both samples were embedded in a transparent polyester resin (Synolite 0328-A-1, DSM Composite Resins AG, Switzerland). Embedded samples were left to set overnight in laboratory conditions $\left(21^{\circ} \mathrm{C}\right.$, $50 \%$ R.H) for the hardening of the resin. Grinding and polishing were carried out using a rotating wet grinder (Labopol 20, Struers, Erkrath, Germany) with different grades of silicon carbide grinding papers $(220,500,2400)$ to obtain the corresponding cross-sections.

Reconstructed paint films were prepared by mixing indigo, Prussian blue and a 50\% wt mixture of indigo and Prussian blue with linseed oil supplied by Kremer Pigmente. Pure pigments and their 1:1 mixture were mixed with the appropriate amount of linseed oil until suitable consistence ( $30 \%$ weight composition of pigment) obtaining the reconstructed paints. After this, each reconstructed paint specimen was spread on glass slides in order to form a thin paint film. Thickness of the prepared films ranged between 0.3 and $0.5 \mathrm{~mm}$. The reconstructed paint films were dried for 4 weeks and then, a first series of analyses was carried out on these unaged reconstructed paint films.

\section{Aging tests}

Two different aging protocols were applied on the pure pigments and their 50\% wt mixture as well as on the reconstructed paint specimens:

a. The set of pure pigments and reconstructed paint films were naturally aged for 2 years $\left(21^{\circ} \mathrm{C}, 50 \%\right.$ $\mathrm{RH}$, daylight illumination in a room oriented to the North). These environmental conditions are representative of the indoor museum conditions in which it is supposed that the studied paintings were stored during the last decades.

b. Accelerated photoaging by irradiating the set of reconstructed paint films in a QUV-Basic chamber with UV lamp UVA-351 nm (Q-Lab Corporation, Cleveland, USA), that emits $25 \mathrm{~W} \mathrm{~m}^{-2}$ mostly at $300-400 \mathrm{~nm}$, simulating the sunlight spectrum (series UVA). Temperature in the aging chamber was maintained at constant value of $45{ }^{\circ} \mathrm{C}$. Specimens were exposed to UVA light for $200 \mathrm{~h}$.

\section{Results and discussion}

Optical, scanning electron and atomic force microscopy

Figure $2 \mathrm{c}$ shows the image of the sample gathered from an altered blue area of the painting. It can be seen that the paint layer exhibits a notable darkening in the surface as consequence of the alteration processes.

The examination of the cross-section of the altered and unaltered paint samples under the optical microscope allowed the recognition of different morphological features in the layered structure of the paint (Fig. 2b, d). The stratigraphic distribution of the samples of the unaltered and altered blue paint comprises a light blue paint layer that, in the sample of the altered blue zone (Fig. 2d), is sub-divided in two sub-layers, (outer and inner) and two reddish ground layers (upper and lower). The outer altered blue paint layer is thinner (at ca $15 \mu \mathrm{m}$ ) than the inner one (at ca $55 \mu \mathrm{m}$ ) and is mainly composed of blue pigment. Micro-particles and dark-blue aggregates of altered blue pigments with variable sizes $(1-5 \mu \mathrm{m})$ can be observed in the outer blue layer. Interestingly, the chromatic alteration is confined to the external $5 \mu \mathrm{m}$ of the outer blue paint layer in the cross-section (Fig. 2c, d), suggesting that the alteration process is a surface phenomenon, a feature also observed in other studies [12]. In the paint layer of the sample from the unaltered blue area and in the inner paint layer of the sample from the altered blue zone can be seen heterometric rounded lead white particles distributed heterogeneously throughout the light-blue microcrystalline matrix. The lower red ground layer presents a heterogeneous texture in which translucent, white and red-ochre small grains are dispersed in a reddish matrix. The upper red ground layer shows similar characteristics but a thinner texture (Fig. 2b, d). Some other morphological features can be seen in the crosssection, such as microcracks across the paint layers, partial loss of the outer paint layer, cavities between the ground and the paint layers, and a disjunction between both ground layers, which highlight the deterioration of this paint sample.

Backscattered electron images acquired on the crosssection of the sample of altered blue zone (Fig. 3a) and energy dispersive X-ray spectrometric analyses (EDX) carried out on this sample revealed well-defined heterometric rounded particles characterized by highly scattering (see arrow a) in the lower paint layer. Lead was detected in these particles whose composition can 


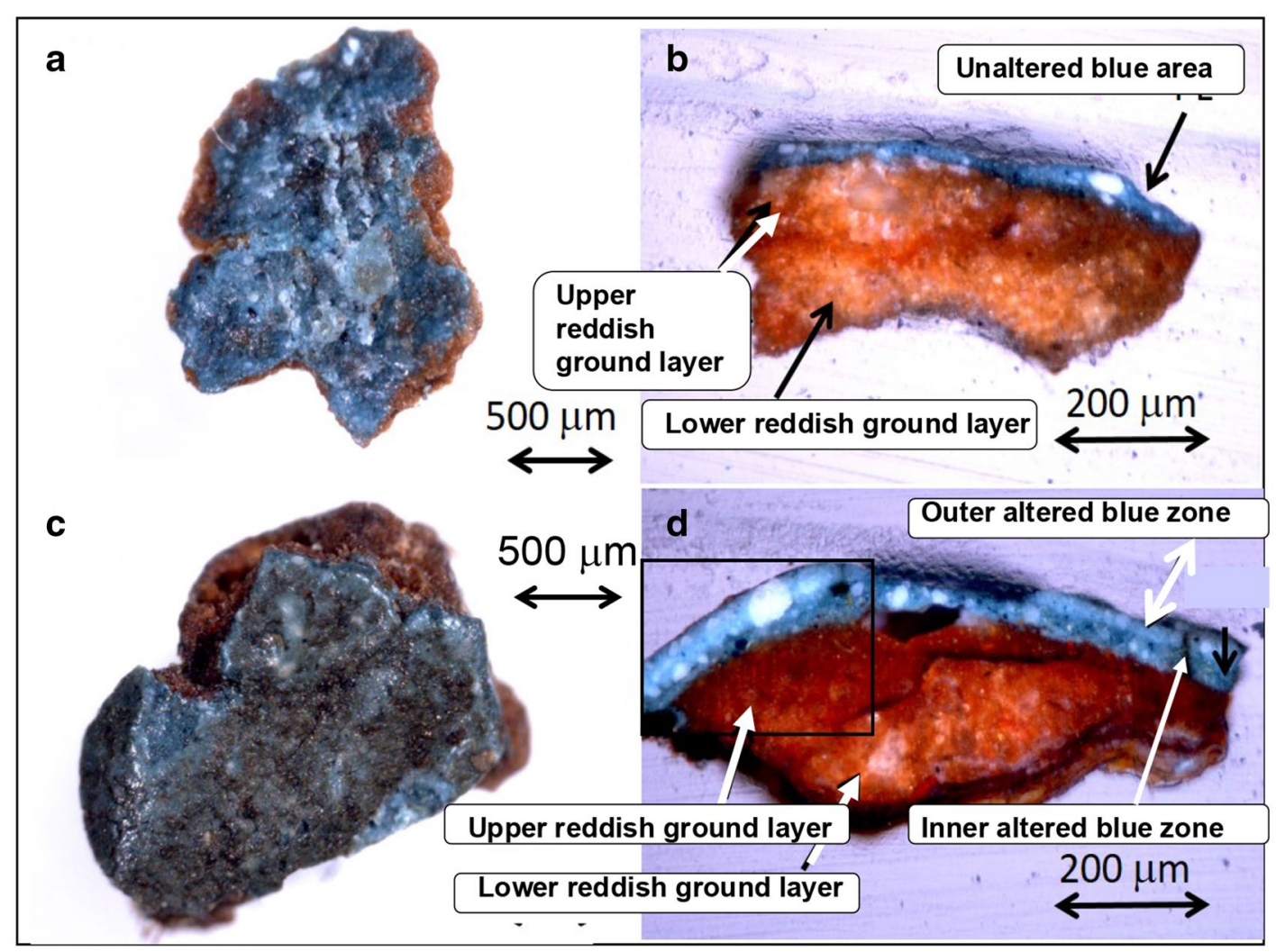

Fig. 2 a Microphotograph of the sample from the blue unaltered paint; $\mathbf{b}$ microphotograph of the cross section of the sample from the blue unaltered paint; $\mathbf{c}$ microphotograph of the sample from the blue altered paint; $\mathbf{d}$ microphotograph of the cross section of the sample from the blue altered paint

be assigned to lead white pigment $\left(2 \mathrm{PbCO}_{3} \cdot \mathrm{Pb}(\mathrm{OH})_{2}\right)$ (Fig. 3b). Furthermore, dark-grey (less scattering) amorphous areas and small particles were also identified in the upper paint layer (arrow b) in which iron is detected in significant proportion, along with potassium (Fig. 3c). The abundance of iron in most parts of the upper layer
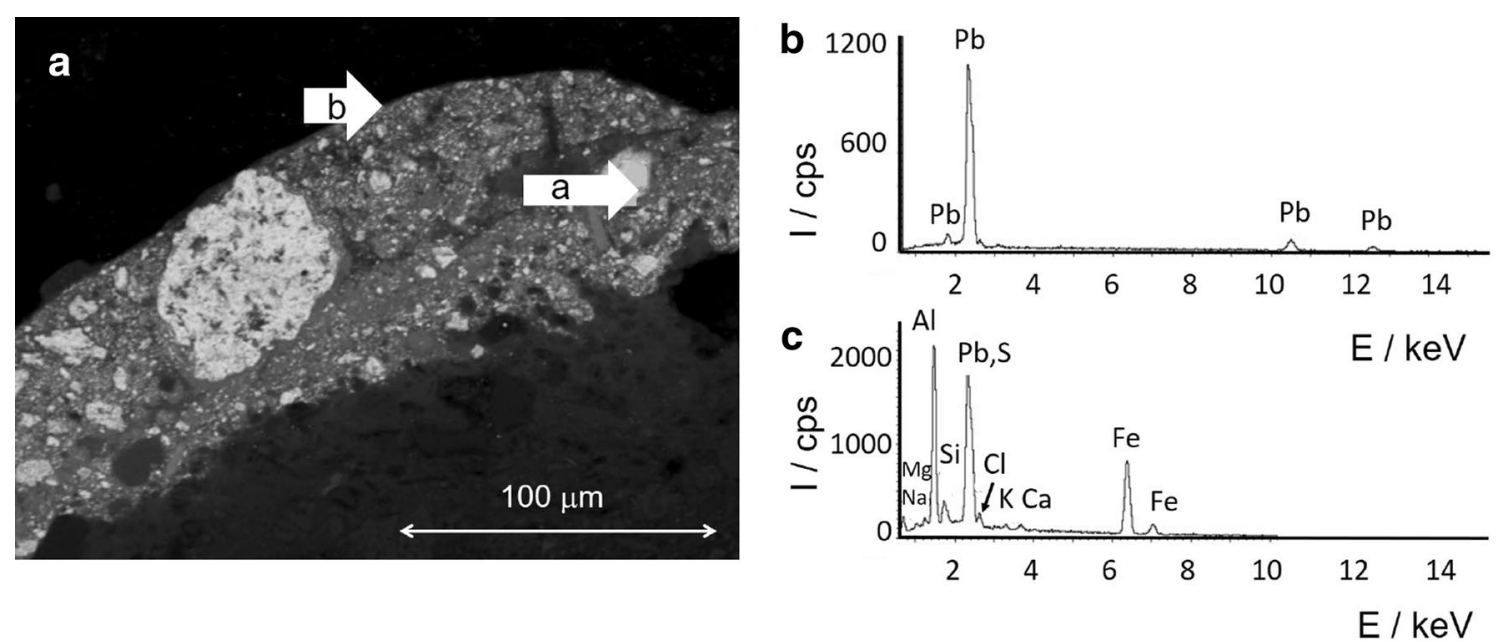

Fig. 3 Scanning electron microscopy-X-ray microanalysis performed in a portion of the cross section of the altered blue sample (area analysed is delimited in the square in Fig. 2d): a backscattered electron image of the the cross-section of the sample (Fig. 2d), $\mathbf{b}$ X-ray spectra acquired in a white grain of lead white located in the lower paint layer (arrow a) and $\mathbf{c} X$-ray spectra acquired in a blue area located in the upper paint layer (arrow b) 
together with potassium suggest the presence of Prussian blue $\left(\mathrm{Fe}_{4}^{\mathrm{III}}\left[\mathrm{Fe}^{\mathrm{II}}(\mathrm{CN})_{6}\right]_{3}\right.$ or $\mathrm{KFe}^{\mathrm{III}}\left[\mathrm{Fe}^{\mathrm{II}}(\mathrm{CN})_{6}\right] \cdot \mathrm{xH}_{2} \mathrm{O}$, depending on the preparation procedure). In contrast, the presence of iron together with aluminium, sulphur and potassium appear to be characteristic of the original method of Prussian blue preparation in which dried blood or another animal matter and alum (aluminium potassium sulphate) as extender were used as ingredients, following the procedure reported by Woodward [49]. However, in some of these dark grey amorphous areas the absence of iron is evident (results not shown) and this feature could suggest the coexistence of an organic pigment such as indigo, precipitated in alum for shading, and/or a deterioration of the Prussian blue pigment due to a lixiviation of the iron ions/solubilization of the Prussian blue. Finally, ground layers show a typical profile of a red earth pigment due to the identification of magnesium, aluminum, silicon, potassium, calcium and iron (results not shown), but the abundance of lead indicates the possible addition of red lead or the diffusion of lead-compounds (such as lead soaps) from the paint upper layers.

Figures 4 and 5 show the topographic images $10 \times 10 \mu \mathrm{m}^{2}$ obtained by means of the atomic force microscope in samples gathered from altered
(Fig. 4) and unaltered (Fig. 5) areas of the painting. It can be seen that the micromorphology in both cases is similar with pigment grains protruding the surface resulting in $\Delta$ high in the range of $1 \mu \mathrm{m}$. It results more interesting the comparison between the values of elastic modulus obtained for paint samples gathered from unaltered and altered areas of the painting, which are summarized in Table 1. It is first worth of mention that the $E M$ values obtained in this research were in the same order as those for the nineteenth century oil paintings reported in other studies that focused on changes in nanomechanical properties while aging oil paintings. [50]. The higher values obtained for the $E M$ in the altered sample were associated with increased stiffness due to the alteration processes taking place in the painting. As it is described in sections thereafter, these alteration processes undergone by the painting have resulted in the hydrolysis of the drying oil and the concomitant depolymerisation and loss of the cross-linking of the oil network. Consequently, the paint film has undergone an increase in stiffness.

\section{FTIR spectroscopy}

The results of the FTIR analysis of the altered paint sample (Fig. 6) evidenced the predominance of absorption
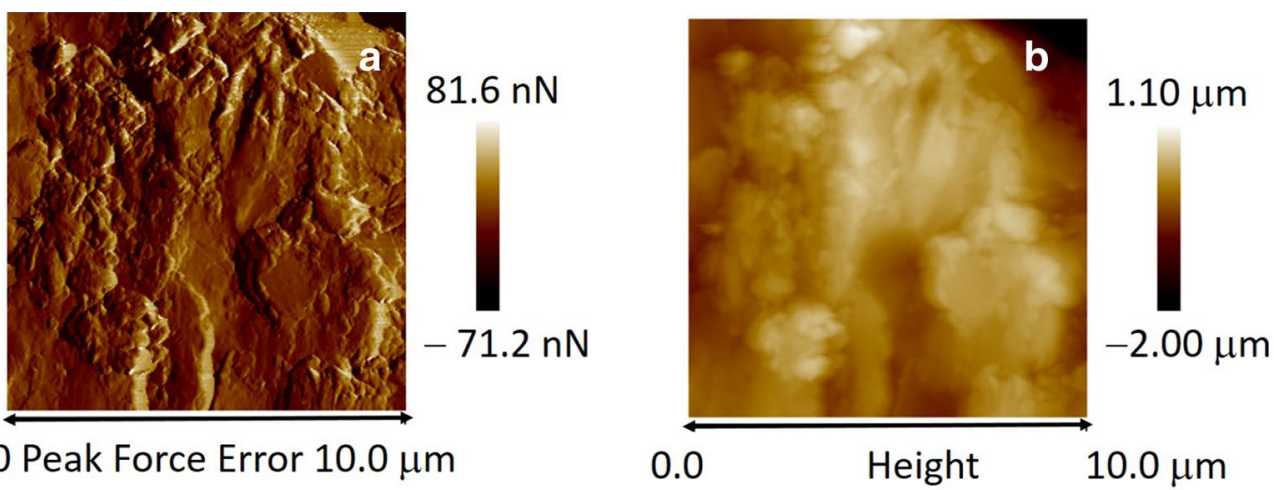

0.0 Peak Force Error $10.0 \mu \mathrm{m}$

0.0

Height

$10.0 \mu \mathrm{m}$

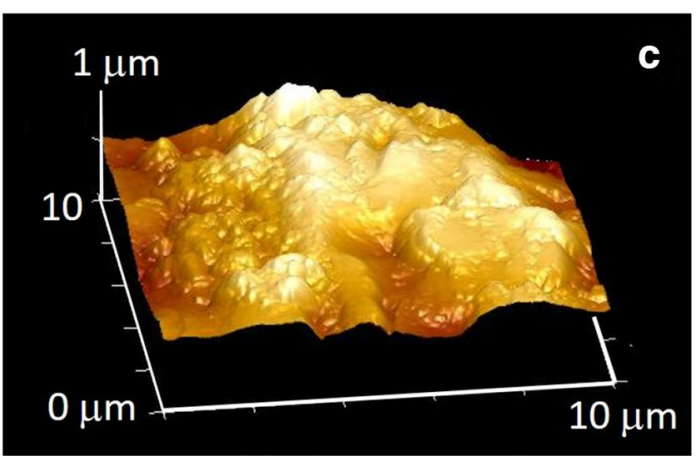

Fig. 4 Sample from blue altered paint a). a Topographic images in peak force error mode ( $X$ and $Y$ scale bar $=10 \mu m, Z=-71.2-81.6 \mathrm{nN})$; $\mathbf{b}$ topographic images in height mode $(X$ and $Y$ scale bar $=10 \mu \mathrm{m}, Z=-2.20-1.10 \mu \mathrm{m})$; c peak force height 3D map $(X$ and $Y$ scale bar $=10 \mu \mathrm{m}$, $\mathrm{Z}=1.00 \mu \mathrm{m})$ 


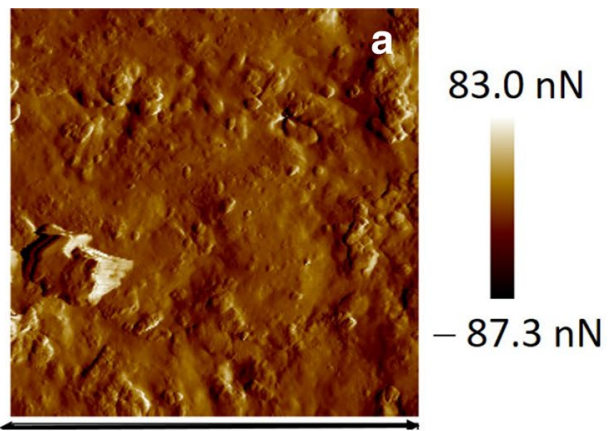

0.0 Peak Force Error $10.0 \mu \mathrm{m}$
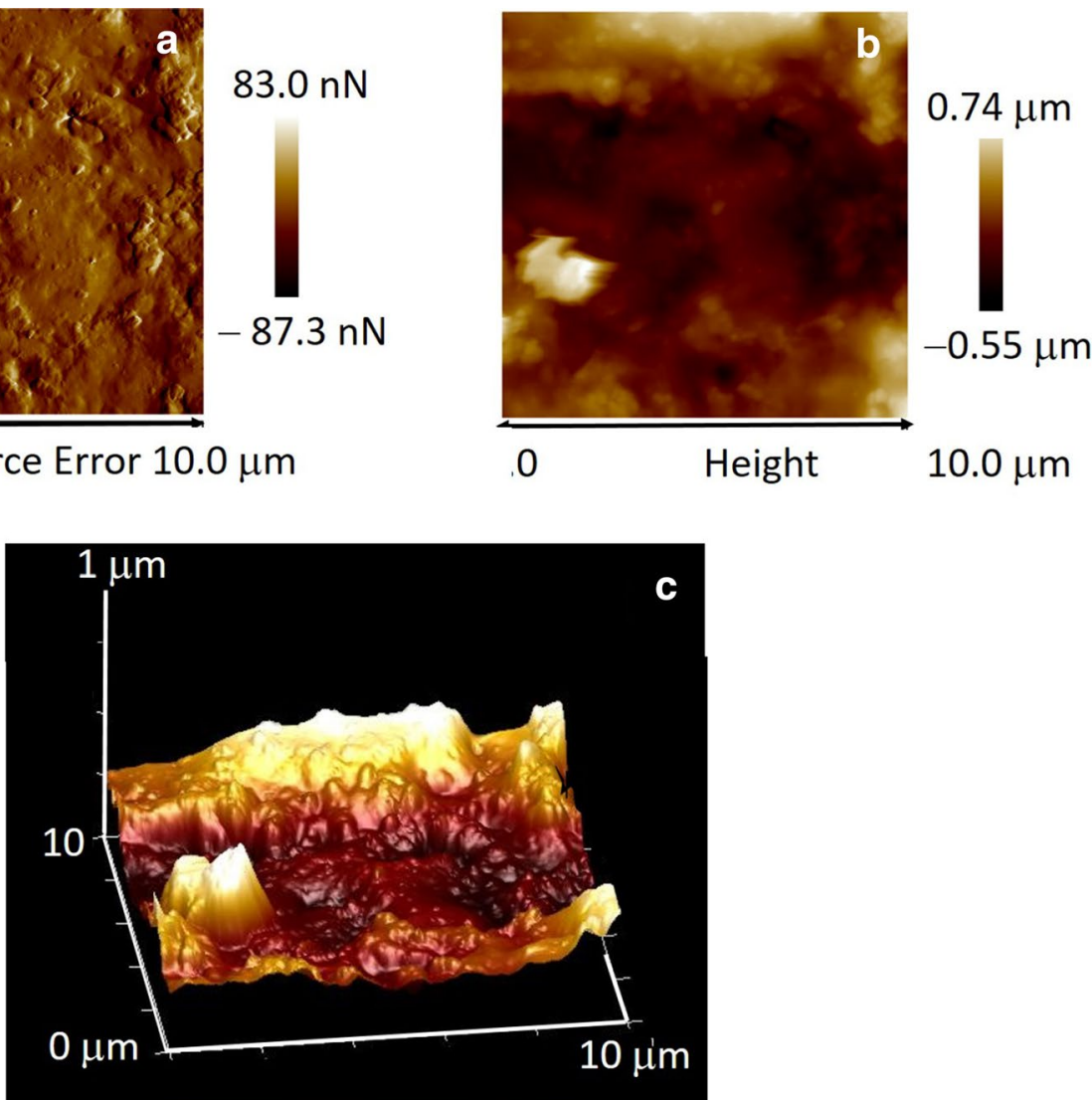

Fig. 5 Sample from blue unaltered paint a). a Topographic images in peak force error mode ( $X$ and $Y$ scale bar $=10 \mu m, Z=-87.3-83.0 \mathrm{nN})$; $\mathbf{b}$ topographic images in height mode ( $X$ and $Y$ scale bar $=10 \mu \mathrm{m}, Z=-0.55-0.74 \mu \mathrm{m})$; c peak force height 3D map $(X$ and $Y$ scale bar $=10 \mu \mathrm{m}$, $\mathrm{Z}=1.00 \mu \mathrm{m})$

bands ascribed to lead carbonate in the basic or hydrocerussite form $\left(2 \mathrm{PbCO}_{3} \cdot \mathrm{Pb}(\mathrm{OH})_{2}\right)$ (absorption bands at 3536, 1393, and $679 \mathrm{~cm}^{-1}$ ) accompanied by calcite bands at 872 and $719 \mathrm{~cm}^{-1}$. In contrast, the absorption bands appearing in the region between 3000 and $2800 \mathrm{~cm}^{-1}$ are related to stretching vibrations of methyl and methylene groups from fatty acid chains, denoting the presence of an organic material of lipidic type as binding medium. This organic material exhibits an advanced state of degradation as it can be seen in the spectral region between 1800 and $1500 \mathrm{~cm}^{-1}$ shown in detail in Fig. 7. In this region it is identified a $\mathrm{C}=\mathrm{O}$ stretching band related to the carboxylic groups in free fatty acids at about $1703 \mathrm{~cm}^{-1}$ with shoulder at ca $1735 \mathrm{~cm}^{-1}$ ascribed to the stretching vibration of carbonyl group of the esters groups in the triacylglycerols of the drying oil. These bands are accompanied by bands attributed to metal carboxylates, mainly lead carboxylates (band at 1506 and shoulder at $1537 \mathrm{~cm}^{-1}$ ) formed between the free fatty acids and the lead ions of the pigment, and oxalates of calcium (weddellite and whewellite at 1643, 1620 and
Table 1 Values of the elastic modulus obtained by means of NI-AFM in microsamples of unaltered and altered paint film gathered from the "San Francesc de Paula" painting

\begin{tabular}{lll}
\hline Elastic modulus & $\begin{array}{l}\text { Unaltered blue } \\
\text { paint (GPa) }\end{array}$ & $\begin{array}{l}\text { Altered blue } \\
\text { paint (GPa) }\end{array}$ \\
\hline Mean value & 6.9 & 10.2 \\
Minimum value & 6.0 & 6.3 \\
Maximum value & 9.4 & 20.4 \\
\hline
\end{tabular}

$\left.1317 \mathrm{~cm}^{-1}\right)$ and lead $\left(1651 \mathrm{~cm}^{-1}\right)$ [14, 51]. In this sense, it should be pointed out that calcium oxalates are more abundant in the altered paint sample than in the unaltered one (results not shown) and these compounds can contribute to the chromatic alterations showed in the painting. Other inorganic compounds were also identified in the IR spectrum such as alum $\left(1097 \mathrm{~cm}^{-1}\right)$, siliceous minerals $\left(1029,942\right.$, and $\left.769 \mathrm{~cm}^{-1}\right)$ and goethite $\left(797^{\text {sh }} \mathrm{cm}^{-1}\right)$ ascribed to earth pigments . Calcite is tentatively identified by overlapped bands with hydrocerussite at 1400, 871 and $719 \mathrm{~cm}^{-1}$. The two last mentioned 


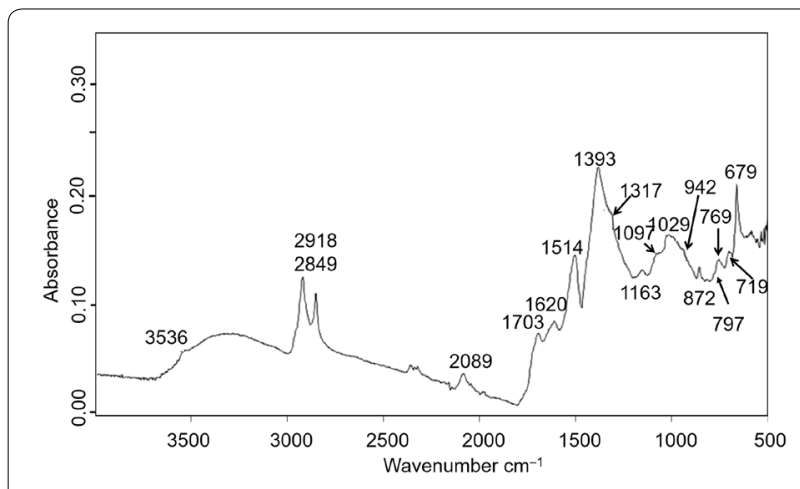

Fig. 6 IR absorption spectra of the paint layer of the altered paint sample

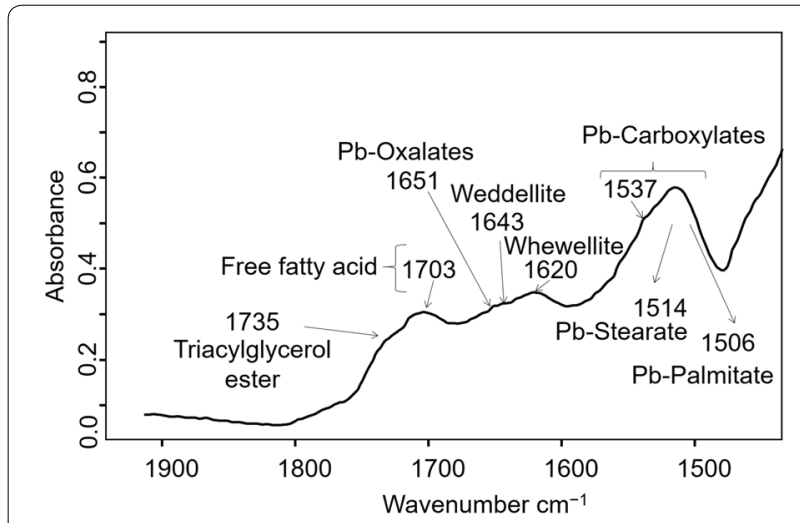

Fig. 7 Detail of the $1800-1500 \mathrm{~cm}^{-1}$ region of the IR spectrum of the altered paint sample shown in Fig. 6

minerals are present in the IR spectrum as residues of the ground layer not removed from the paint layer due to the difficulty of accurately separate both layers by mechanical tools. The identification of these ground residues in the IR spectrum of the paint layer was confirmed by comparing it with the IR spectrum of a sample of ground shown in Additional file 1: Figure S1.

A low intensity absorption band with a maximum at $2089 \mathrm{~cm}^{-1}$ related to the stretching vibration of $\mathrm{CN}$ group confirms the presence of Prussian blue in accordance with the results of SEM/EDX. The broadening of this band and the shoulder at $2050 \mathrm{~cm}^{-1}$ suggest the coexistence of different species with various oxidation states formed through redox reactions of this pigment [52]. However, the considerable overlap between the absorption bands of the organic and inorganic compounds present in the paint samples makes difficult the confirmation of the coexistence of other pigments such as indigo.
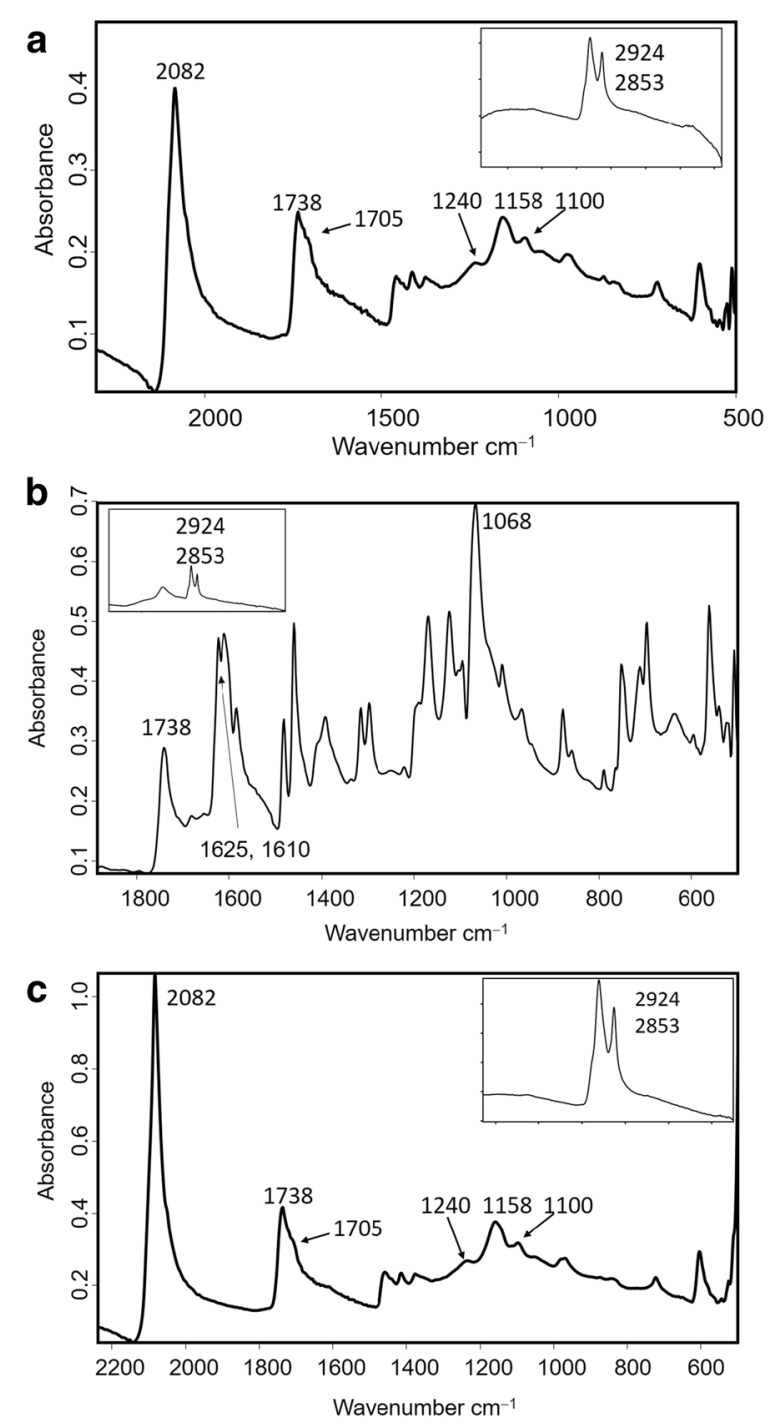

Fig. 8 IR absorption spectra of reconstructed paint films: a Prussian blue + linseed oil; b Indigo + linseed oil; c Prussian blue + indigo + linseed oil

Figure 8 shows the IR absorption spectra of the reconstructed paint specimens made with Prussian blue (Fig. 8a), indigo (Fig. 8b) and the mixture 1:1 indigoPrussian blue (Fig. 8c). The IR spectrum of Prussian blue + oil paint film is dominated by a strong band at $2082 \mathrm{~cm}^{-1}$ ascribed to the stretching vibration of $\mathrm{CN}$ group. Indigo + oil paint film exhibits abundant IR bands in the fingerprint region dominated by the bands at 1738 and $1068 \mathrm{~cm}^{-1}$ accompanied by a moderate band at 1625 and a new very weak band at $1610 \mathrm{~cm}^{-1}$. This band can be ascribed to the stretching vibration of $\mathrm{C}=\mathrm{O}$ group in indigo and other organic molecules present in natural indigo (see Additional file 1: Figure S2). Linseed oil 
is recognized in both IR spectra by sharp bands at 2924 and $2853 \mathrm{~cm}^{-1}$ associated with the stretching vibrations of methyl and methylene groups in triacylglycerol molecules and by the band at $1738 \mathrm{~cm}^{-1}$ ascribed to the carbonyl bond in the ester groups of triacylglycerol molecules. The IR spectrum of the indigo-Prussian blue + oil reconstructed paint film is a combination of the IR spectra of both pigments plus the drying oil (Fig. 8c). This last IR spectrum is dominated by the Prussian blue band of CN groups at $2082 \mathrm{~cm}^{-1}$. Moderate bands of carbonyl stretching at $1738 \mathrm{~cm}^{-1}$ and $\mathrm{C}-\mathrm{O}$ stretching vibrations at 1240,1158 and $1100 \mathrm{~cm}^{-1}$ ascribed to the linseed oil are also present. Interestingly, a weak shoulder at $1705 \mathrm{~cm}^{-1}$ is also recognized. This feature, like that found at $1703 \mathrm{~cm}^{-1}$ in the altered sample (Fig. 7), that is exclusively observed in reconstructed paint films containing Prussian blue (Additional file 1: Figures S3, S4), can be ascribed to stretching vibrations of free fatty acids released by the hydrolysis reaction undergone by the triacylglycerol molecules of the linseed oil. It is of worth to mention that in FTIR spectroscopy is very common that the same IR band found in diverse samples undergoes
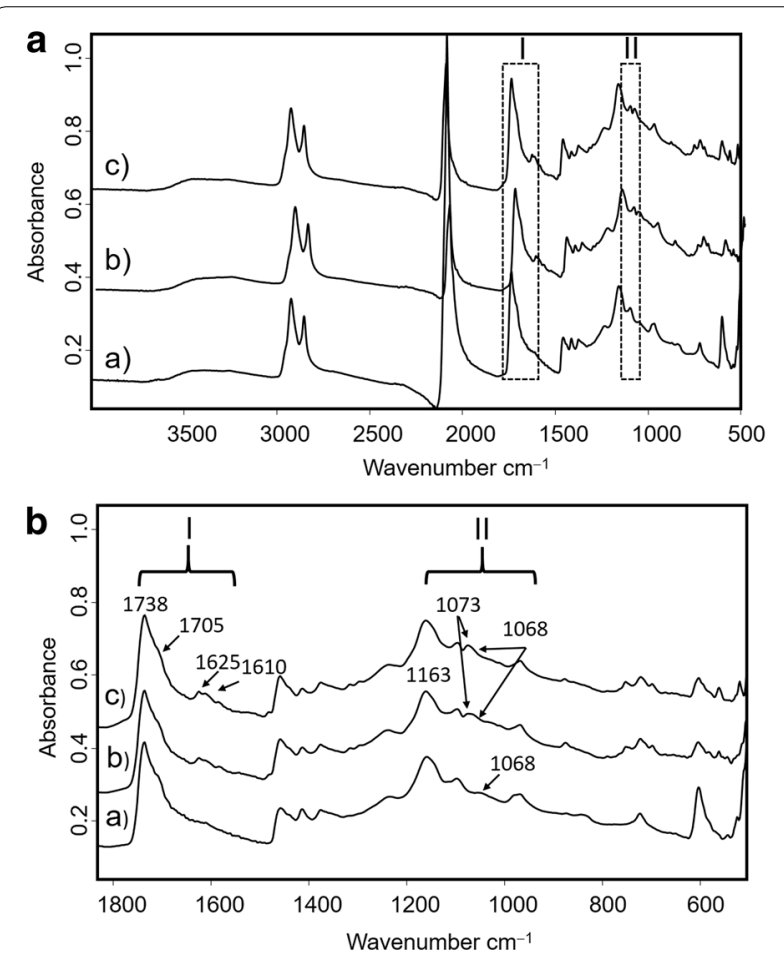

Fig. 9 IR absorption spectra of reconstructed paint films indigo + Prussian blue + oil. a Entire IR spectrum $\left(4000-600 \mathrm{~cm}^{-1}\right)$ b Detail of the IR spectra shown in Fig. 9a. Offset I: 1800-1600 cm-1 region; offset II: $1100-1000 \mathrm{~cm}^{-1}$ region. For each figure: a) IR spectrum of unaged reconstructed paint film; b) IR spectrum of the reconstructed paint film naturally aged; $c$ ) IR spectrum of the reconstructed paint film after accelerated UVA aging

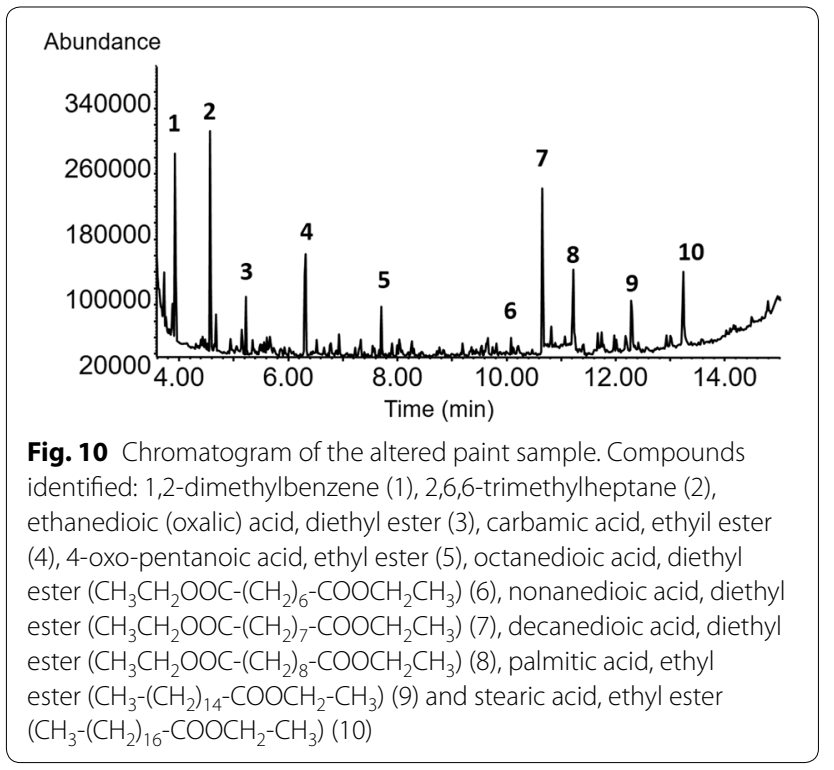

band maximum differences of a few $\mathrm{cm}^{-1}$ when this band is not ascribed to an individual compound. The IR band at $1703 / 1705 \mathrm{~cm}^{-1}$ is associated to a mixture of free fatty acids (palmitic, stearic, azelaic, oleic acid, etc.) each one with a specific position for its band maximum. Thus, depending on the history of the painting, the percentage distribution of fatty acids composing the paint varies and, concomitantly, the maximum of the experimental band of fatty acids is blue- or redshifted a few $\mathrm{cm}^{-1}$.

Figure 9a shows the IR spectrum of the indigo-Prussian blue + oil reconstructed paint film after drying (IR spectrum a) and the reconstructed paint films naturally aged (IR spectrum $\mathrm{b}$ ) and subjected to accelerated aging with UVA light (IR spectrum c). These samples display changes in spectral regions I $\left(1800-1600 \mathrm{~cm}^{-1}\right)$ and II $\left(1100-1000 \mathrm{~cm}^{-1}\right)$ that can be seen in detail in Fig. 9b and Additional file 1: Figures S4-S9 (Additional file 1). Interestingly, increase of band at $1610 \mathrm{~cm}^{-1}$ ascribed to carbonyl band in organic molecules as well as a new peak at $1073 \mathrm{~cm}^{-1}$, ascribed to stretching vibrations of $\mathrm{OH}$ groups, occurs in both naturally and accelerated UVA aged paint films (see Additional file 1: Figures S7-S9).

\section{Gas chromatography-mass spectrometry}

With the purpose of completely characterizing the organic materials used as binding medium in the painting, and thus, complementing the results obtained by FTIR spectroscopy, representative fragments of the altered and unaltered paint samples were analyzed by means of GC-MS. The chromatogram obtained for the altered paint sample is shown in Fig. 10. Peaks 1-3 are not of analytical interest as they are artefacts from the 
solvents and reagents used in the extraction-derivatization pre-treatment. Peak 4 reveals the presence of oxalic acid from the metal oxalates formed as a result of the degradation of the binder and further complexation with metal ions from the pigments. Peak 5 is identified as 4-oxo-pentenoic acid, probably an oxidation product of low molecular weight formed as result of the oil aging. Peaks 9 and 10 identify monocarboxylic even-numbered saturated fatty acids containing 16 and 18 carbon atoms, with stearic acid (18:0) as the most abundant. Peaks 6-8 are short-chain dicarboxylic acids with 8,9 and 10 carbon atoms. These short chain fatty acids, which are present in a significant proportion, were formed due to oxidation processes undergone by the unsaturated fatty acids (oleic, linoleic and linolenic) that form the molecules of triacylglycerols in the drying oil. A similar chromatographic profile was obtained for the paint sample from the unaltered area (results not shown).

The occurrence of these compounds confirms the presence of an organic material of lipid type as binder. Interestingly, the $\mathrm{P} / \mathrm{S}$ ratio (chromatographic peak area of palmitic acid $P$ versus chromatographic peak area of stearic acid S) obtained is $0.6-0.7$, which is not adjusted for the expected values for linseed oil (1.2-1.5), walnut oil (1.8-2.0), poppy oil (1.6-1.8) or mixtures of them, commonly used in oil paintings [53]. This deviation in the $\mathrm{P} / \mathrm{S}$ value indicates a significant variation in the content of fatty acid constituents of the drying oil as a consequence of the high degree of alteration of the binding medium. The results obtained point out to an extensive hydrolysis process taking place during aging and the subsequent formation of metal-carboxylate complexes (metal soaps) between the free-fatty acids of the oil and the metal ions of the pigments, as confirmed by infrared analysis. Metal soaps can crystallize from the ionomeric phase in the paint film or react with other constituents from the paint or the environment resulting in new alteration products such as oxalates, as also shown in the results obtained by the infrared analysis.

\section{Voltammetric pattern}

Due to its capacity to minimize distorting capacitive effects, potentially important in solid insulating materials, square wave voltammetry was used in the electrochemical study [27-29]. Figure 11 shows the square wave voltammograms of microparticulate deposits of (a) indigo and (b) isatin abrasively transferred onto the surface of graphite electrodes in contact with $0.25 \mathrm{M} \mathrm{HAc/}$ $\mathrm{NaAc}$ aqueous buffer at $\mathrm{pH}$ 4.75. These are accompanied by the voltammograms corresponding to (c) unaltered and (d) altered layers of the Sant Francesc de Paula paint. Upon scanning the potential in the negative direction, indigo (Fig. 11a) displays two well-defined peaks at -0.30 (I) and $0.45 \mathrm{~V}$ vs. $\mathrm{Ag} / \mathrm{AgCl}$ (II) corresponding, respectively, to the reduction of indigo (IND, 1) to leucoindigo (LEU, 2) and the oxidation of indigo to dehydroindigo (DHI, 6). These two proton-assisted solid-state processes are summarized in Scheme 1 and can be represented as [37-40]:

$$
\begin{aligned}
& \{\text { IND, } \mathbf{1}\}_{\text {solid }}+2 \mathrm{H}_{\mathrm{aq}}^{+}+2 \mathrm{e}^{-} \rightarrow\{\mathrm{LEU}, 2\}_{\text {solid }} \\
& E_{\text {red }}=-0.30 \mathrm{~V} \text {, peak I } \\
& \{\mathrm{IND}, \mathbf{1}\}_{\text {solid }} \rightarrow\{\mathrm{DHI}, \mathbf{6}\}_{\text {solid }}+2 \mathrm{H}_{\mathrm{aq}}^{+}+2 \mathrm{e}^{-} \\
& \quad E_{\text {oxid }}=+0.45 \mathrm{~V} \text {, peak II }
\end{aligned}
$$

In turn, isatin (4) produces a unique, intense cathodic peak at ca. $-0.70 \mathrm{~V}$ (III) (Fig. 11b), corresponding to the proton-assisted reduction to hydroxylated derivatives (possibly $1 \mathrm{H}$-indole-2,3-diol, $\mathbf{5}$, see Scheme 1 ) [40, 54].

The unaltered blue submicrosample (Fig. 11c) yields the indigo-localized peaks I and II accompanied by broad peaks at $-0.15(\mathrm{IV})$ and $0.80 \mathrm{~V}(\mathrm{~V})$. On the basis of abundant literature on the electrochemistry of this compound [34-36] and our blank experiments in synthetic specimens, these peaks can be unambiguously attributed to Prussian blue centred processes (vide infra). The complete or partial oxidation of Prussian blue yields Prussian yellow $\left(\mathrm{Fe}^{\mathrm{III}}\left[\mathrm{Fe}^{\mathrm{III}}(\mathrm{CN})_{6}\right]\right)$ or Berlin green, respectively. This last is a solid solution of Prussian blue and Prussian yellow $\left\{\mathrm{KFe}^{\mathrm{III}}\left[\mathrm{Fe}^{\mathrm{II}}(\mathrm{CN})_{6}\right\}_{x}\left\{\mathrm{Fe}^{\mathrm{III}}\left[\mathrm{Fe}^{\mathrm{III}}(\mathrm{CN})_{6}\right]\right\}_{1-x}\right.$, [55]. The reduction of Prussian blue yields Berlin white or Everitt's salt, a Fe ${ }^{\mathrm{II}}$ hexacyanoferrate(II), complex [55].

The observed voltammetric processes correspond, respectively, to the reduction of $\mathrm{Fe}(\mathrm{III})$ centres and the oxidation of $\mathrm{Fe}(\mathrm{II})$ ones coupled to the entrance/issue of electrolyte charge-balancing cations [34-36]. In agreement with prior studies $[56,57]$, signals attributable to lead white were recorded only in positive-going voltammograms appearing as weak anodic signals at ca. $-0.50 \mathrm{~V}$. The voltammetric peaks IV and $\mathrm{V}$ can be represented as [34-36]:

$$
\begin{aligned}
\mathrm{KFe}^{\mathrm{III}}\left[\mathrm{Fe}^{\mathrm{II}}(\mathrm{CN})_{6}\right]_{\text {solid }}+\mathrm{K}_{\mathrm{aq}}^{+}+\mathrm{e}^{-} \\
\rightarrow \mathrm{K}_{2} \mathrm{Fe}^{\mathrm{II}}\left[\mathrm{Fe}^{\mathrm{II}}(\mathrm{CN})_{6}\right]_{\text {solid }} E_{\text {red }}=\sim-0.05 \mathrm{~V} \text {, peak IV } \\
\mathrm{KFe}^{\mathrm{III}}\left[\mathrm{Fe}^{\mathrm{II}}(\mathrm{CN})_{6}\right]_{\text {solid }} \rightarrow \mathrm{Fe}^{\mathrm{III}}\left[\mathrm{Fe}^{\mathrm{III}}(\mathrm{CN})_{6}\right]_{\text {solid }} \\
\quad+\mathrm{K}_{\mathrm{aq}}^{+}+\mathrm{e}^{-} E_{\text {oxid }}=\sim+0.75 \mathrm{~V}, \text { peak V }
\end{aligned}
$$

where $\mathrm{KFe}^{\mathrm{III}}\left[\mathrm{Fe}^{\mathrm{II}}(\mathrm{CN})_{6}\right]$ is Prussian blue, $\mathrm{K}_{2} \mathrm{Fe}^{\mathrm{II}}\left[\mathrm{Fe}^{\mathrm{II}}(\mathrm{CN})_{6}\right]_{\text {solid }}$ is Berlin white, and $\mathrm{Fe}^{\mathrm{III}}\left[\mathrm{Fe}^{\mathrm{III}}(\mathrm{CN})_{6}\right]_{\text {solid }}$ is Prussian yellow. Interestingly, the voltammograms of submicrosamples extracted from the altered regions of the paint show intense signals III and IV while the indigo signals and the Prussian 
blue signal $\mathrm{V}$ vanish (Fig. 11d). These features suggest that there is an oxidation of indigo to isatin and Prussian blue to Berlin green responsible for the chromatic change of the paint. It is pertinent to note that, in agreement with literature, the electrochemical processes I, II [37-40], as well as the processes IV and V [34-36] can be considered as electrochemically reversible as judged by their appearance in both negative- and positive-going potential scans and the values of half-width potentials. In contrast, isatin reduction (process III) behaves irreversibly $[40,54]$.

\section{Degradation pathways}

The most relevant voltammetric features recorded for indigo, Prussian blue and reconstructed paint film specimens submitted to the aging protocols described in the Experimental section are summarized in Figs. 12 and 13 (see also Additional file 1: Figure S10). The former superimposes the negative-going potential scan voltammograms of indigo, Prussian blue and a 50\% wt mixture of these components, clearly showing the indigo-centred signals I and II and the Prussian blue centred peaks IV and $\mathrm{V}$.

In Fig. 13, the electrochemical responses of indigo plus Prussian blue mixtures (a) and indigo plus Prussian blue plus linseed oil reconstructed paint films (b) before and after application of natural and accelerated UVA aging protocols, are superimposed. The voltammetric features of pigments and paint specimens after natural and accelerated UVA aging were essentially identical. Semiderivative convolution of data in general increases peak resolution. An example is provided as Additional file 1: Figure S10. The most relevant features can be summarized as:

a. In the pure pigments, as well as in pigment mixtures, natural aging produces a decrease in the indigo II peak without concomitant decrease of the signal I, a light increase in the Prussian blue signal IV without variation of the signal $\mathrm{V}$, all these features being accompanied by the appearance of a new voltammetric peak at ca. $0.85 \mathrm{~V}(\mathrm{VI})$. Upon natural and accelerated UVA aging, the decrease of the indigo signal becomes more pronounced while the peak VI becomes clearly enhanced. This last signal can tentatively be attributed to a species resulting from the hydroxyl addition to the indigo molecule (dihydroxyindigo, 3, see Scheme 1) whose electrochemical oxidation should occur at high potentials.

b. The paint oil specimens show the Prussian blue signal $\mathrm{V}$ clearly depleted relative to the indigo signals. Natu-

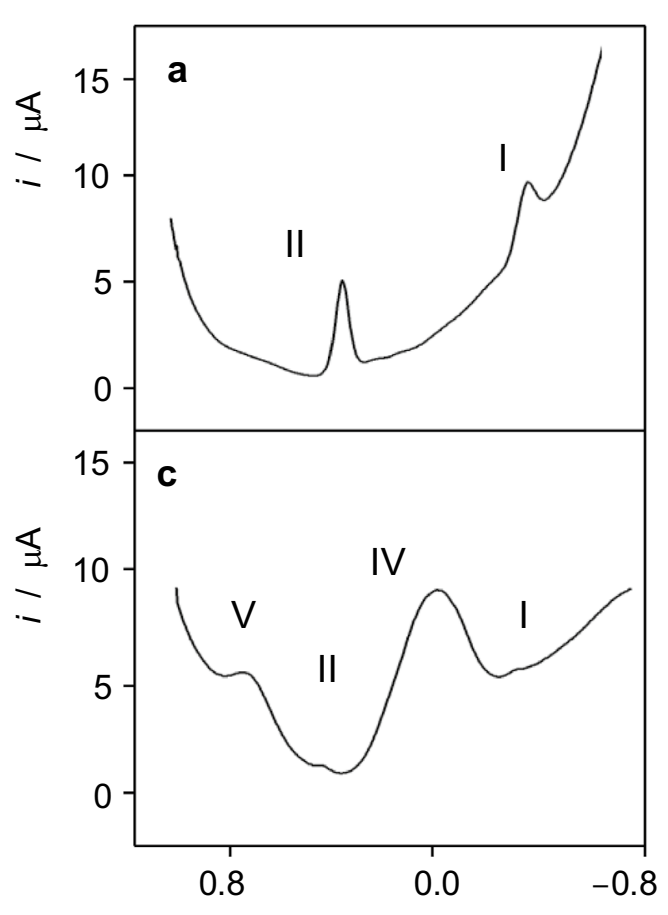

E / V vs. Ag|AgCl

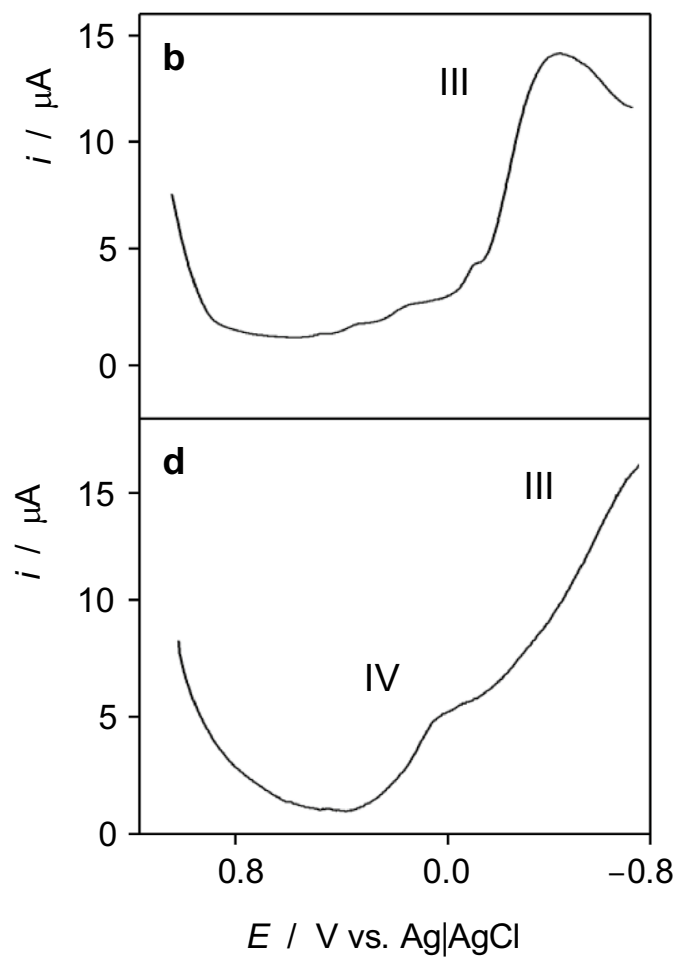

Fig. 11 Square wave voltammograms of microparticulate deposits of $\mathbf{a}$ indigo, $\mathbf{b}$ isatin, and submicrosamples extracted from $\mathbf{c}$ unaltered and $\mathbf{d}$ altered layers of the Sant Francesc de Paula paint, all attached to graphite bar immersed into air-saturated $0.25 \mathrm{M} \mathrm{HAc/NaAc} \mathrm{aqueous} \mathrm{buffer} \mathrm{at} \mathrm{pH}$ 4.75. Potential scan initiated at $1.05 \mathrm{~V}$ in the negative direction, potential step increment $4 \mathrm{mV}$, square wave amplitude $25 \mathrm{mV}$, frequency $5 \mathrm{~Hz}$ 


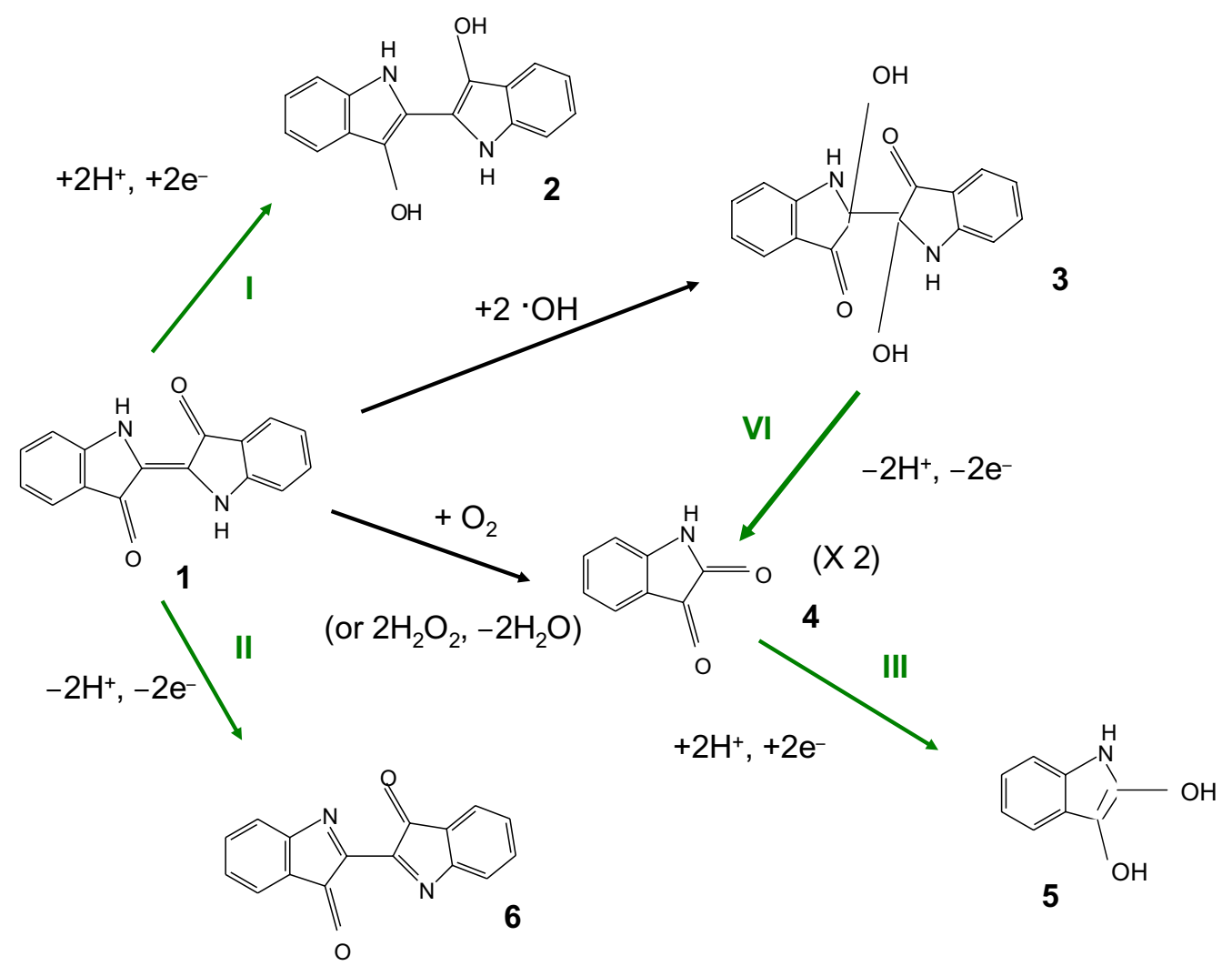

Scheme 1 Molecular structures of the compounds produced by the electrochemical, green arrows, reactions I, II, III, and VI, and the chemical, black arrow, reactions for the various indigo chemical reactions studied herein. The molecular structures shown are for indigo, IND, $\mathbf{1}$; leucoindigo, LEU, 2; dihydroxyindigo, 3; isatin, 4; 1 H-indole-2,3-diol, 5; and dehydroindigo, $\mathrm{DHI}, 6$

ral aging determines the same features described for the pure pigments, but here the Prussian blue signals become enhanced. Under accelerated UVA aging, the peak VI is considerably enhanced whereas both indigo peaks I and II are depleted.

c. In all indigo-containing specimens, the isatin signature (peak III) appears upon aging, being particularly enhanced when accelerated UVA aging was applied.

These voltammetric data are consistent with infrared spectral features. As can be seen in Fig. 9, appearance of a new stretching band of $\mathrm{C}=\mathrm{O}$ groups at $1605 \mathrm{~cm}^{-1}$ and a new weak band at $1073 \mathrm{~cm}^{-1}$, in principle attributable to $\mathrm{OH}$ groups, on specimens submitted to natural and accelerated UVA aging, suggests diversification of organic molecules during the alteration of paint films. Appearance of the carbonyl signal at $1705 \mathrm{~cm}^{-1}$ only in reconstructed paint films that contain Prussian blue, suggests that the hydrolysis process undergone by the linseed oil is promoted by the Prussian blue pigment.

These features can be interpreted on the basis of studies on the degradation of indigo and Prussian blue pigments [42-59]. The indigo degradation is in principle promoted by oxidants [42], being particularly intense the degradation produced by light [43]. According to Inga et al. [44], there are two (main) indigo degradation pathways catalyzed by hydroxyl $(\cdot \mathrm{OH})$ and hydroperoxyl $(\cdot \mathrm{OOH})$ radicals. The hydroxyl-catalyzed degradation can lead to dehydroindigo via intermediate formation of an indigo radical anion via proton abstraction, or via $\mathrm{OH}$ addition to the central $\mathrm{C}=\mathrm{C}$ indigo bond. Ultimately, indigo photodegradation yields isatin, isatoic anhydride and anthranilic acid $[42-44,58]$ whereas indigo degradation by ozone yields isatin and isatoic anhydride [59].

In regard to Prussian blue, Samain et al. [20, 55] have reported that it can be partially oxidized to Berlin green $\left(\mathrm{KFe}^{\mathrm{III}}\left[\mathrm{Fe}^{\mathrm{II}}(\mathrm{CN})_{6}\right]\right)_{\mathrm{x}}\left(\mathrm{Fe}^{\mathrm{III}}\left[\mathrm{Fe}^{\mathrm{III}}(\mathrm{CN})_{6}\right]\right)_{1-\mathrm{x}}$. The degradation 
process appears to be facilitated in the presence of linseed oil binder and lead white, leading to the reduction of Prussian blue to Berlin white, $\mathrm{K}_{2} \mathrm{Fe}^{\mathrm{II}}\left(\mathrm{Fe}^{\mathrm{II}}(\mathrm{CN})_{6}\right.$, at the exposed paint surface and an oxidation to Berlin green in the bulk of the paint layer [20]. Then, the formation of isatin and other indigo degradation products and Berlin green can be responsible for the observed chromatic alteration in the Sant Francesc de Paula painting.

The polymerization of drying oils produces free radicals (alcoxyl, .OR, alkoxyperoxyl, .OOR) derived from hydroperoxides [21], able to promote the above oxidation reactions. Accordingly, the formation of isatin, and hence, the orange-brownish hue acquired by the degraded zones of the Sant Frances de Paula paint, can be attributed to the oxidation of indigo promoted by free radicals generated in the oil binding media. As previously noted, this situation is mainly reproduced in paint specimens prepared from indigo without Prussian blue. The minor presence or even the absence of isatin in the aged samples containing both Prussian blue and indigo, can be interpreted on considering the peculiar characteristics of the interaction of the first pigment with reactive oxygen species. This compound acts as catalyst for $\mathrm{H}_{2} \mathrm{O}_{2}$ reduction under electrochemical conditions $[60,61]$ where it appears to be partially dissolved releasing $\mathrm{Fe}^{2+}(\mathrm{aq})$ and ferrocyanide associated to local production of $\mathrm{HO}^{-}$, so that $\mathrm{Fe}^{2+}$ (aq) ions initiate the Fenton reaction with $\mathrm{H}_{2} \mathrm{O}_{2}$ generating hydroxyl radicals [61]. On the contrary, in the

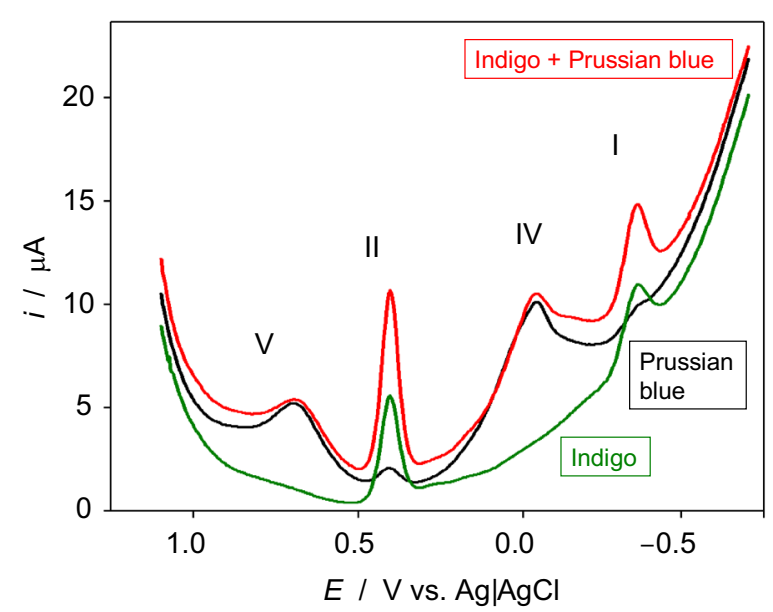

Fig. 12 Square wave voltammograms of microparticulate deposits of indigo (green), Prussian blue (black), and a 50\% wt mixture of indigo and Prussian blue (red), attached to graphite bar immersed into air-saturated 0.25 M HAc/NaAc solution at pH 4.75. Potential scan initiated at $1.05 \mathrm{~V}$ in the negative direction, potential step increment $4 \mathrm{mV}$, square wave amplitude $25 \mathrm{mV}$, frequency $5 \mathrm{~Hz}$

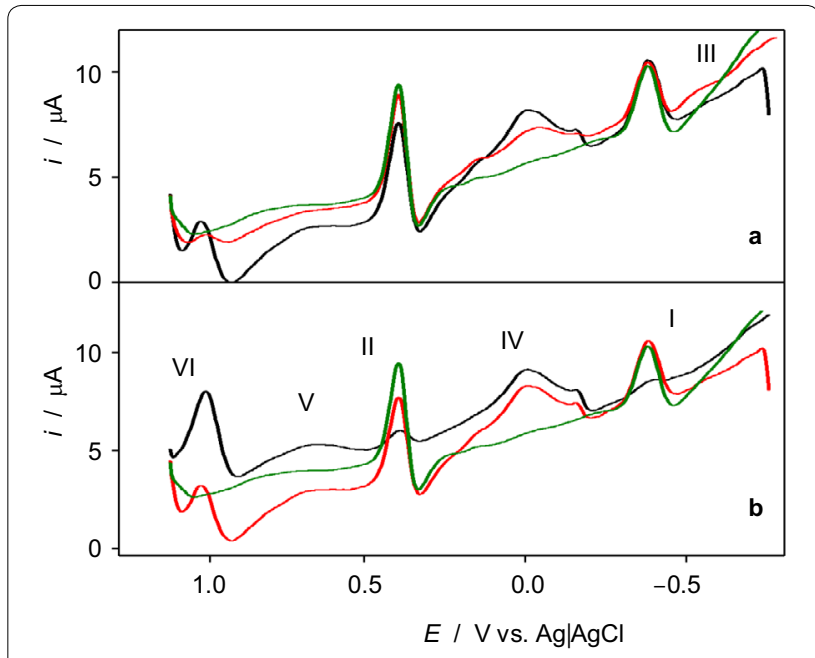

Fig. 13 Square wave voltammograms, after semi-derivative convolution, of sample-modified graphite electrodes in contact with air-saturated 0.25 M HAc/NaAc aqueous buffer at pH 4.75. a 50\% wt indigo plus Prussian blue mixture before (green) and after being naturally aged (red) and after accelerated UVA aging (black); b indigo plus Prussian blue paint film specimens before (green) and after being naturally aged (red) and after accelerated UVA aging (black). Voltammograms in conditions such as in Fig. 12

absence of electrochemical inputs, Prussian blue nanoparticles act as radical scavengers, in particular abstracting $\cdot \mathrm{OH}$ radicals mimicking the activity of peroxidases $[62,63]$.

The different degradation pathways observed in reconstructed paint film specimens and localized areas of the Sant Francesc de Paula paint can be interpreted, in the light of the previous considerations, taking into account that the grain size and the nature of the local binding environment can affect significantly the stability of the pigments [58, 64]. Under moderate temperature, humidity, illumination and low gradients of these parameters, as is the case of the prepared paint film specimens, Prussian blue, acts as radical scavenger [61, 62], being slowly oxidized to Berlin green. Then, indigo degradation takes place through adduct formation with radicals, as schematically depicted in Scheme 1.

In the case of the Sant Francesc de Paula paint, since the canvas was rolled up and re-mounted onto a wooden frame and subsequently re-varnished [33], the produced fissures provided opportunity for a reinforced action of light and humidity on the pigment layers. Here, Prussian blue acts as an initiator of the Fenton reaction [60] rather than a radical scavenger and promotes the oxidation of indigo to isatin. This process formally results from the reaction of indigo with $\mathrm{O}_{2}$, or, possibly, with $\mathrm{H}_{2} \mathrm{O}_{2}$ formed, in the absence of radical scavenging, by condensation of hydroxyl radicals. Scheme 2 shows an idealized 


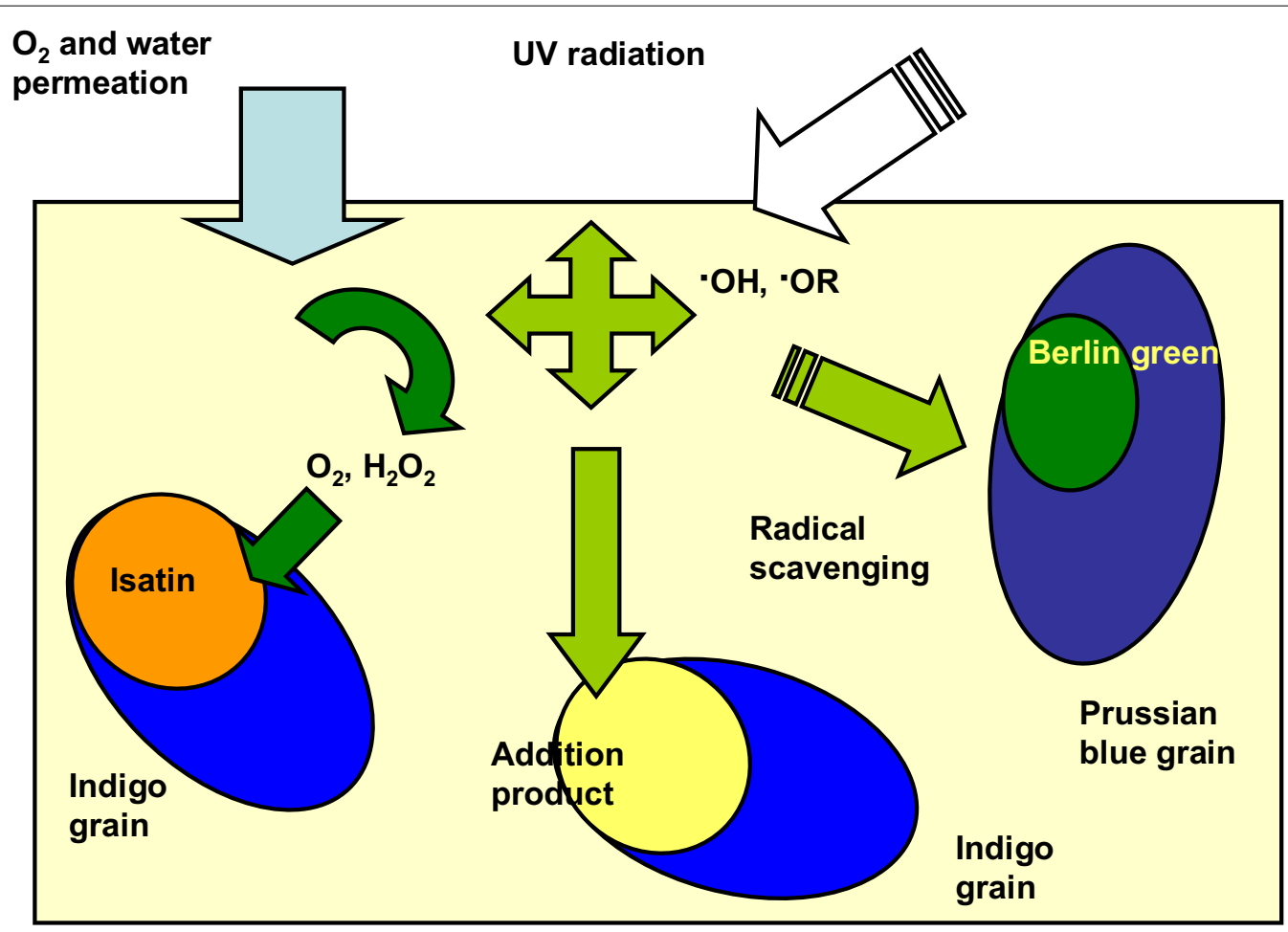

Scheme 2 Schematic representation of the degradation processes in indigo plus Prussian blue oil paints

scheme of the possible processes involved in pigment degradation.

\section{Conclusions}

The degradation of oil paints containing indigo and Prussian blue pigments has been studied by solid state electrochemistry aided by light microscopy, scanning electron microscopy-energy dispersive X-ray analysis, nanoindentation-atomic force microscopy, attenuated total reflectance-Fourier-transform infrared spectroscopy and gas chromatography-mass spectroscopy. Voltammetry of immobilized particles data on sub-microsamples from reconstructed oil paint specimens and samples from the Sant Francesc de Paula painting from the Tomàs Balvey Arxiu Museum permit to detect the presence of isatin and Berlin green in highly degraded areas of the paint, resulting in a significant chromatic shift respect to unaltered light-blue areas.

Voltammetric data on samples from paint specimens naturally aged and submitted to accelerated UVA aging can be interpreted on the basis of a dual reaction scheme in which the action of reactive oxygen species produced in the binding medium interacts with indigo and Prussian blue. Under normal conditions of indoor museum exhibition or usage, this compound acts as a selective radical scavenger determining the preferential addition of reactive oxygen species to the $\mathrm{C}=\mathrm{C}$ central bond of indigo. Under drastic conditions of degradation, as is the case of localized areas of the Sant Francesc de Paula painting, Prussian blue acts as an oxidation promoter of the indigo oxidation to isatin. Conjointly considered, the reported data illustrate the capabilities of the voltammetry of immobilized particles to acquire information on complex systems.

\section{Supplementary information}

Supplementary information accompanies this paper at https://doi. org/10.1186/s40494-020-00415-x.

Additional file 1. Supplementary information containing additional IR and VIMP data.

\section{Abbreviations}

AFM: Nanoindentation-atomic force microscopy; ATR-FTIR: Attenuated total reflectance-Fourier transform infrared spectroscopy; DHI: Dehydorindigo; SEM-EDX: Scanning electron microscopy coupled to energy dispersive X-ray detection; EM: Elastic modulus; FTIR: Fourier-transfor infrared spectroscopy; GC-MS: Gas chromatography-mass spectrometry; IND: Indigo; IR: Infrared; LEU: Leucoindigo; MATBC: Tomàs Balvey Arxiu Museum, Cardedeu, Spain; NI-AFM: Nanoindentation-atomic force microscopy; NIST: National Institute of Science and Technology; UVA: Ultraviolet radiation of longer wavelength.

\section{Acknowledgements}

The authors wish to thank Teresa Blanch Bofill, director of the Museu Arxiu Tomàs Balvey de Cardedeu (MATBC, Barcelona) for generous access to the painting and for organizing the Jornada d'estudi de la pintura de Sant Francesc de Paula to discuss the results of the research conducted by GRAPAC-CETEC Patrimoni de la UAB-IQS/URL, Institut Universitari de Restauració del Patrimoni 
(IRP) de la Universitat Politècnica de València and Universitat de València and to the Oficina de Patrimoni Cultural de la Diputació de Barcelona in which Conservation Programme the intervention of the painting and preliminary studies were technically and financially supported. The authors wish to thank Mr. Manuel Planes, Dr. José Luis Moya and Alicia Nuez Inbernón technical supervisors of the Electron Microscopy Service of the Universitat Politècnica de València,

\section{Authors' contributions}

ADC: design and coordination of the study and modeling electrochemical data; MTDC: performance of laboratory specimens, AFM-nanoindentation and design and coordination of the study and interpretation of AFM-indentation, infrared and SEM-EDX data; LOC: performance of accelerated aging of specimens, morphological analysis of paint samples using optical and Scanning Electron Microscopy, SEM-EDX, GC-MS and FTIR analysis and data interpretation; MD: performance and interpretation of voltammetric data; NGF: analysis chemical and mineralogic using light microscopy and SEM-EDX and participation in data interpretation; RGF: preliminary studies, diagnosis and conservation treatment of the painting; MAl: stratigraphic description and analysis mineralogic using light microscopy and participation in data interpretation. All authors read and approved the final manuscript.

\section{Funding}

Financial support was received from the MINECO Project CTQ2017-85317-C21-P which is supported with Ministerio de Economía, Industria y Competitividad (MINECO) and Fondo Europeo de Desarrollo Regional (ERDF) and Agencia Estatal de Investigación (AEI).

\section{Availability of data and materials}

All data are available on request.

\section{Competing interests}

None of the authors have any competing interest in the manuscript.

\section{Author details}

${ }^{1}$ Departament de Química Analítica, Universitat de València, Dr. Moliner, 50, 46100 Burjassot, València, Spain. ${ }^{2}$ Institut de Restauració del Patrimoni, Universitat Politècnica de València, Camí de Vera 14, 46022 Valencia, Spain. ${ }^{3}$ Dipartimento di Scienze Molecolari e Nanosistemi, Università Cà Foscari Venezia, Via Torino 155, 30172 Mestre-Venezia, Italy. ${ }^{4}$ Departament d'Arts i Conservació-Restauració, Facultat de Belles Arts, Universitat de Barcelona, Carrer Pau Gargallo, 4, 08028 Barcelona, Spain. ${ }^{5}$ Laboratori de Conservació-Restauració, Oficina de Patrimoni Cultural de la Diputació de Barcelona, Carrer Comte d'Urgell, 187, 08036 Barcelona, Spain. ${ }^{6}$ Grup de Recerca Aplicada al Patrimoni Cultural (GRAPAC/CETEC-patrimoni), Departament de Geologia, Facultat de Ciències, Carrer dels Til-lers, rup de Recerca Aplicada al Patrimoni Cultural (GRAPAC/CETEC-patrimoni), Universitat Autònoma de Barcelona, Campus de la UAB, 08193 Bellaterra, Catalonia, Spain.

\section{Received: 22 April 2020 Accepted: 4 July 2020}

\section{Published online: 16 July 2020}

\section{References}

1. Matteini M, Moles A. La Chimica nel Restauro. Firenze: Nardini; 1989.

2. Mills JS, White R. The organic chemistry of museum objects. London: Buttersworth; 1994.

3. Berrie BH, Strumfels Y. Change is permanent: thoughts on the fading of cochineal-based watercolor pigments. Herit Sci. 2017;5:5-30.

4. Erhardt D, Tumosa CS, Mecklenburg MF. Long-term chemical and physical processes in oil paint films. Stud Conserv. 2005;50:143-50.

5. Meilunas RJ, Bentsen JG, Steinberg A. Analysis of aged paint binders by FTIR spectroscopy. Stud Conserv. 1990;35:33-51.

6. Mallégol J, Lemaire J, Gardette JL. Drier influence on the curing of linseed oil. Progr Org Coat. 2009;39:107-13

7. Breitbach AM, Rocha JC, Gaylarde CC. Influence of pigment on biodeterioration of acrylic paint films in Southern Brazil. J Coat Technol Res. 2011:8:619-28.

8. Robinet $\mathrm{L}$, Corbeil MC. The characterization of metal soaps. Stud Conserv. 2003:48:23-40.
9. Plater MJ, De Silva B, Gelbrich T, Hursthouse MB, Higgitt CL, Saunders DR. The characterization of lead fatty acid soaps in "protusions" in aged traditional oil paint". Polyhedron. 2003;22:3171-9.

10. Cotte M, Checroun E, Susini J, Dumas P, Tchoereloff P, Bernard M, Walter P. Kinetics of oil saponification by lead salts in ancient preparations of pharmaceutical lead plasters and painting lead mediums. Talanta. 2006;70:1136-42.

11. Mazzeo R, Prati S, Quaranta M, Joseph E, Kendix E, Galeotti M. Attenuated total reflection micro FTIR characterization of pigment-binder interaction in reconstructed paint films. Anal Bioanal Chem. 2008:392:65-76.

12. Keune K, van Loon A, Boon JJ. SEM Backscattered-Electron images of paint cross sections as information source for the presence of the lead white pigment and lead-related degradation and migration phenomena in oil paintings. Micros Microanal. 2011;22:448-57.

13. Keune K, Boon JJ. Analytical imaging studies of Saint cross-sections illustrate the oil paint defect of lead soap aggregate formation. Stud Conserv. 2007:52:161-76.

14. Salvadó N, Butí S, Nicholson J, Emerich H, Labrador A, Pradell T. Identification of reaction compounds in micrometric layers from gothic paintings using combined SR-XRD and SR-FTIR. Talanta. 2009;79:419-28.

15. Genestar $C$, Pons $C$. Earth pigments in painting: characterization and differentiation by means FTIR spectroscopy. Anal Bioanal Chem. 2005:382:269-74

16. Casanova-González E, García-Bucio A, Ruvalcaba-Sil JL, Santos-Vasquez V, Esquivel B, Falcón T, Arroyo E, Zetina S, Roldán ML, Domingo C. Surfaceenhanced Raman spectroscopy spectra of Mexican dyestuffs. J Raman Spectrosc. 2012;43:1551-9.

17. Higgitt C, Spring M, Saunders D. Pigment-medium interactions in oil paint films containing red lead or lead-tin yellow. Natl Gallery Tech Bull. 2003;24:75-96.

18. Keune K, Van Loon A, Boon JJ. SEM backscatteredelectron images of paint cross-sections as information source for the presence of the lead white pigment and lead-related degradation and migration phenomena in oil paintings. Microsc Microanal. 2011;17:696-701.

19. Kirby J, Saunders D. Fading and colour Change of Prussian blue: methods of manufacture and the influence of extenders. Natl Gallery Techn Bull. 2004:25:73-99.

20. Samain L, Gilbert B, Grandjean F, Long GJ, Strivay D. Redox reactions in Prussian blue containing paint layers as a result of light exposure. J Anal Atom Spectrom. 2013;28:524-35.

21. Weerd J, Van Der Loon A, Boon JJ. FTIR studies of the effects of pigments on the aging of oil. Stud Conserv. 2005;50:3-22.

22. Cotte $M$, Checroun $E$, De Nolf W, Taniguchi Y, De Viguerie L, Burghammer M, Walter P, Rivard C, Salomé M, Janssens K, Susini J. Lead soaps in paintings: friends or foes? Stud Conserv. 2017;62:2-23.

23. De Santis A, Mattei E, Pelosi C. Micro-Raman and stratigraphic studies of the paintings on the 'Cembalo' Model musical instrument (AD 1650) and laser-induced degradation of the detected pigments. J Raman Spectrosc. 2007;38:1368-78.

24. Scholz F, Meyer B. Voltammetry of solid microparticles immobilized on electrode surfaces. Electroanal Chem. 1998;20:1-86.

25. Scholz F, Schröder U, Gulabowski R, Doménech-Carbó A. Electrochemistry of immobilized particles and droplets. 2nd ed. Berlin-Heidelberg: Springer; 2014.

26. Doménech-Carbó A, Labuda J, Scholz F. Electroanalytical chemistry for the analysis of solids: characterization and classification (IUPAC Technical Report). Pure Appl Chem. 2013;85:609-31.

27. Doménech-Carbó A, Doménech-Carbó MT, Costa V. Electrochemical methods for archaeometry, conservation and restoration (monographs in electrochemistry series scholz F edit). Berlin: Springer; 2009.

28. Doménech-Carbó A. Electrochemistry for conservation science. J Solid State Electrochem. 2010;14:349-51.

29. Doménech-Carbó A, Doménech-Carbó MT. Electroanalytical techniques in archaeological and art conservation. Pure Appl Chem. 2018;90:447-62.

30. Ortiz-Miranda AS, Doménech-Carbó A, Doménech-Carbó MT, Osete-Cortina L, Bolívar-Galiano FF, Martín-Sánchez I, López-Miras MM. Electrochemical characterization of biodeterioration of paint films containing cadmium yellow pigment. J Solid State Electrochem. 2016;20:3287-302.

31. Ortiz-Miranda AS, Doménech-Carbó A, Doménech-Carbó MT, OseteCortina L, Bolívar-Galiano FF, Martín-Sánchez I. Analyzing chemical changes in verdigris pictorial specimens upon bacteria and fungi biodeterioration using voltammetry of microparticles. Herit Sci. 2017;5:8. 
32. WAA. "Sant Francesc de Paula". Anàlisi d'una restauració in Jornada tècnica sobre la restauració de l'obra pictòrica de Sant Francesv [Francesc] de Paula, 16 juny, 2017, Cardedeu, Barcelona.

33. Gasol R. Memòria de la conservació-restauració del quadre "Sant Francesc de Paula" (Núm. Reg. 2258) del Museu Arxiu Tomàs Balvey de Cardedeu. Oficina de Patrimoni Cultural de la Diputació de Barcelona. Barcelona: 2016.

34. Scholz F, Dostal A. The formal potentials of the solid metal hexacyanometalates. Angew Chem Int Ed. 1995;34:2685-7.

35. Dostal A, Meyer B, Scholz F, Schröder U, Bond AM, Marken F, Shaw SJ. Electrochemical study of microcrystalline solid prussian blue particles mechanically attached to graphite and gold electrodes: electrochemically induced lattice reconstruction. J Phys Chem. 1995;99:2096-103.

36. Dostal A, Kauschka G, Reddy SJ, Scholz F. Lattice contractions and expansions which accompany the electrochemical conversion of Prussian blue and the reversible and irreversible insertion of rubidium and thallium ions. J Electroanal Chem. 1996;406:155-63.

37. Bond AM, Marken F, Hill E, Compton RG, Hügel H. The electrochemical reduction of indigo dissolved in organic solvents and as a solid mechanically attached to a basal plane pyrolytic graphite electrode immersed in aqueous electrolyte solution. J Chem Soc Perkin Trans. 1997;2:1735-42.

38. Komorsky-Lovric S, Mircevski V, Scholz F. Voltammetry of organic microparticles. Mikrochim Acta. 1999;132:67-77.

39. Doménech-Carbó A, Doménech-Carbó MT, Vázquez De Agredos-Pascual ML. Dehydroindigo: a new piece into the maya blue puzzle from the voltammetry of microparticles approach. J Phys Chem B. 2006;110:6027-39.

40. Doménech-Carbó A, Doménech-Carbó MT, Vázquez De Agredos-Pascual ML. Electrochemical monitoring Maya Blue preparation from Maya's ancient procedures. J Solid State Electrochem. 2007;11:1335-46.

41. Grosjean D, Whitmore PM, Cass GR. Ozone fading of natural organic colorants - mechanisms and products of the reaction of ozone with indigos. Environ Sci Technol. 1988;22:292-8.

42. Novotná P, Boon JJ, van der Horst J. Pacákova V Photodegradation of indigo in dichloro-methane solution. Color Technol. 2003;119:121-7.

43. Yamazaki S, Sobolewski AL, Domcke W. Molecular mechanisms of the photostability of indigo. PhysChemChemPhys. 2011;13:1618-28.

44. Inga C, Ortíz E, Alvarez-Idaboy JR, Vivier-Bunge A. Molecular description of indigo oxidation mechanisms initiated by $\mathrm{OH}$ and $\mathrm{OOH}$ radicals. J Phys Chem A. 2012;116:3643-51.

45. Van Espen P. Electron probe X-ray microanalysis. In: Fitzgerald AF, Storey BE, Fabian D, editors. Quantitative microbeam analysis. Bristol: Institute of Physics Publishing; 1992.

46. Derjaguin BV, Muller VM, Toropov YuP. Effect of contact deformations on the adhesion of particles. J Colloid Interface Sci. 1975;53:314-26.

47. Lee Y, Martín-Rey S, Osete-Cortina L, Martín-Sánchez I, Bolívar-Galiano F. Doménech-Carbó MT Evaluation of a gelatin-based adhesive for historic paintings that incorporates citronella oil as an eco-friendly biocide. J Adhes Sci Technol. 2018;32:2320-49.

48. Doménech-Carbó MT, Casas-Catalán MJ, Doménech-Carbó A, MateoCastro R, Gimeno-Adelantado JV, Bosch-Reig F. Analytical study of canvas painting collection from the Basilica de la Virgen de los Desamparados using SEM/EDX, FT-IR, GC and electrochemical techniques. Fresenius' J Anal. Chem. 2001;369:571-5.

49. Woodward, J. Praeparato caeruli Prussiaci ex Germania missa ad Johannem Woodward. Philosophical Transactions. XXXIII, no. 381, January-February 1724, pp. 15-17.

50. Salvant J, Barthel E, Menu M. Nanoindentation and the micromechanics of Van Gogh oil paints, hal-00593798; 2011. http://hal.archives-ouvertes.fr. Accessed 02 Apr 2020.
51. Monico L, Rosi F, Miliani C, Daveri A, Brunetti BG. Non-invasive identification of metal-oxalate complexes on polychrome artwork surfaces by reflection mid-infrared spectroscopy. Spectrochim. Acta A Mol Biomol Spectrosc. 2013;116:270-80.

52. Christensen PA, Hamnett A, Higgins SJ. A study of electrochemically grown Prussian blue films using Fourier-transform infrared spectroscopy. J Chem Soc Dalton Trans 1990; 2233-8.

53. Wang N, He L, Zhao X, Simon S. Comparative analysis of eastern and western drying-oil binding media used in polychromic artworks by pyrolysisgas chromatography/mass spectrometry under the influence of pigments. Microchem J. 2015;123:201-10.

54. Diculescu VC, Kumbhat S, Oliveira-Brett AM. Electrochemical behaviour of isatin at a glassy carbon electrode. Anal Chim Acta. 2006;575:190-7.

55. Grandjean F, Long GJ, Samain L. The pivotal role of mössbauer spectroscopy in the characterization of prussian blue and related iron cyanide complexes. Mössbauer Effect Ref Data J. 2012;35:143-53.

56. Doménech-Carbó A, Doménech-Carbó MT, Mas-Barberá X. Identification of lead pigments in nanosamples from ancient paintings and polychromed sculptures using voltammetry of nanoparticles/atomic force microscopy. Talanta. 2007;71:1569-79.

57. Doménech-Carbó A, Doménech-Carbó MT, Peiró-Ronda MA. 'One-touch' voltammetry of microparticles for the identification of corrosion products in archaeological lead. Electroanalysis. 2011;23:1391-400.

58. Castañeda Delgado M. El índigo en la pintura de caballete novohispana: mecanismos de deterioro. Intervención. 2019;1:25-35.

59. Ben Hmida S, Ladhari N. Study of parameters affecting dry and wet ozone bleaching of denim fabric. Ozone Sci Eng. 2015;38:175-80.

60. Chumming $\mathrm{P}$, Xianqing J. Electrochemical synthesis of $\mathrm{Fe}_{3} \mathrm{O}_{4}-\mathrm{PB}$ nanoparticles with core-shell structure and its electrocatalytic reduction toward $\mathrm{H}_{2} \mathrm{O}_{2}$. J Solid State Electrochem. 2009;13:1273-8.

61. Prabhu P, Suresh Babu R, Sriman Narayanan S. Synergetic effect of Prussian blue film with gold nanoparticle graphite-wax composite electrode for the enzyme-free ultrasensitive hydrogen peroxide sensor. J Solid State Electrochem. 2014;18:883-91.

62. Noël J-M, Médard J, Combellas C, Kanoufi F. Prussian blue degradation during hydrogen peroxide reduction: a scanning electrochemical study on the role of the hydroxide ion and hydroxyl radical. ChemElectroChem. 2016;3:1178-84.

63. Zhang W, Hu S, Yin JJ, He W, Lu W, Ma W, Gu N, Zhang Y. Prussian blue nanoparticles as multienzyme mimetics and reactive oxygen species scavenger. J Am Chem Soc. 2016;138:5860-5.

64. Chen J, Wang Q, Huang L, Zhang H, Rong K, Zhang H, Dong S. Prussian blue with intrinsic heme-like structure as peroxidase mimic. Nano Res. 2018;11:4905-13.

\section{Publisher's Note}

Springer Nature remains neutral with regard to jurisdictional claims in published maps and institutional affiliations.

\section{Submit your manuscript to a SpringerOpen ${ }^{\circ}$ journal and benefit from:}

- Convenient online submission

- Rigorous peer review

- Open access: articles freely available online

- High visibility within the field

- Retaining the copyright to your article

Submit your next manuscript at springeropen.com 